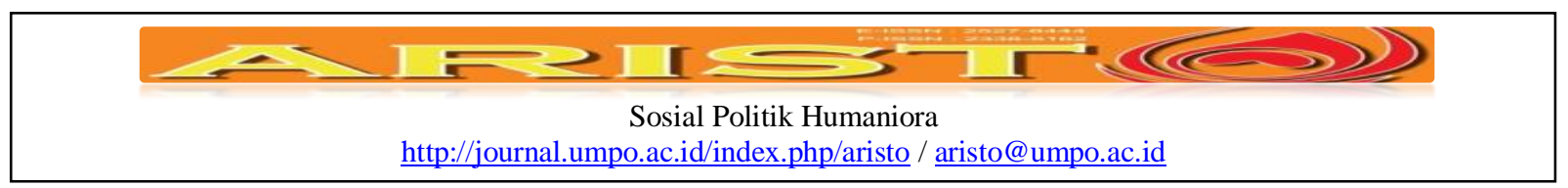

\title{
Budaya Populer Dalam Pertunjukkan Reyog Obyogan
}

\author{
Oki Cahyo Nugroho, Hadi Purwanir \\ Program Studi Ilmu Komunikasi, FISIP, \\ Universitas Muhammadiyah Ponorogo. \\ okicahyo@umpo.ac.id
}

\begin{abstract}
Pop culture is often associated with a community environment with certain characteristics such as beliefs, rituals, performances, form shows, lifestyle patterns, symbols, language, dress, music, dance, and various models form of human expression, intellectual, and how to communicate in a order a certain time.In Reyog Obyogan performances, pop culture can we find is the traditional musical accompaniment or wasps that incorporate elements of today's popular such as dangdut songs. Not only that, the dancers jathil freely change and adjust according to the demand of the audience or trends that are favored in society. Seeing this paradigm and development, the focus in this research is to look further and in-depth how a popular culture trending affect community shape in a staging performances Reyog Ponorogo in Obyogan form.It also affects the patterns of communication, the message and meaning contained within the show itself. Result of this study showed several behaviors in Reyog Obyogan performances influences to a popular culture that were hits in the present like a concept similar to the dance Edreg Jaipong. Saweran also started a lot in the form of performances Reyog. Song or "Gending" in reyog also changing from songs like 'walang kekek" being "oplosan"' or 'kanggo riko' which is present in vogue in society. The costumes also changed with the entry of sensual especially against Jathil dancers are semi-transparent clothing similar to the Kebaya and colorful. The conclusion of this study prove that folk art as a tradisional performance be affected things that are popular in the community at large at the time.
\end{abstract}

Keyword : Brexit, Eurosceptic, United Kingdom, European Union, Referendum

\begin{abstract}
Abstrak
Budaya pop sering dihubungkan dengan lingkungan masyarakat dengan ciri khas tertentu seperti kepercayaan, ritual, pertunjukkan, bentuk pertunjukkan, pola gaya hidup, simbol, bahasa, pakaian, musik, tarian,dan berbagai macam model bentuk ekspresi manusia, intelektual, dan cara berkomunikasi dalam sebuah tatanan waktu tertentu. Dalam pertunjukkan reyog obyogan, budaya pop yang bisa kita jumpai adalah gending atau tabuhan pengiring yang memasukkan unsur-unsur lagu dangdut populer saat ini dimasyarakat. Tidak hanya itu, para penari jathil dengan leluasa mengubah dan menyesuaikan sesuai dengan permintaan dari penonton atau tren yang sedang disenangi dalam masyarakat.Melihat paradigma dan perkembangan inilah, fokus dalam penelitan ini adalah melihat lebih jauh dan mendalam bagaimana sebuah budaya populer yang sedang tren dimasyarakat mempengaruhi bentuk pertunjukkan dalam sebuah pementasan reyog ponorogo dalam bentuk obyogan. Hal ini juga mempengaruhi pola komunikasi, pesan yang disampaikan dan makna yang terkandung dalam pertunjukkan itu sendiri secara tidak sadar.Hasil dari penelitian ini menunjukkan beberapa perilaku dalam pertunjukkan reyog obyogan mengarah pada budaya popular yang sedang hits pada saat sekarang seperti konsep edreg yang mirip dengan tari jaipong. Saweran juga mulai banyak dalam bentuk pertunjukkan reyog ini. Lagu atau gending dalam reyog juga mengalami perubahan dari lagu-lagu seperti
\end{abstract}

Oki Cahyo Nugroho, Hadi Purwanir. Budaya Populer dalam pertunjukkan reyog Obyogan / 02 / Vol.5. No. 1. Tahun 2017 


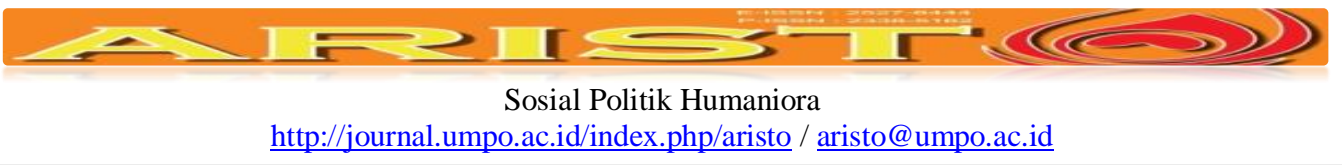

'walang kekek' menjadi 'oplosan' atau 'kanggo riko' yang saat sekarang sedang digemari di masyarakat. Kostum juga mengalami perubahan dengan masuknya unsur sensual terutama terhadap penari jathil yaitu pakaian semi transparan yang mirip dengan kebaya dan berwarnawarni. Kesimpulan dari penelitian ini membuktikan bahwa kesenian rakyat yang bersifat tradisionalpun dapat terpengaruh hal-hal yang sedang digemari dalam masyarakat pada umumnya pada saat itu.

Keyword: Budaya Populer, Komunikasi, Reyog ponorogo

\begin{tabular}{|ll|}
\hline Submite & $:$ 14 Nov 2016 \\
Review & $:$ 20 Nov 2016 \\
Accepted & $:$ 01 Jan 2017 \\
Surel Corespondensi & $:$ jovani.audra@gmail.com /adamhilman@umpo.ac.id \\
\hline
\end{tabular}

\section{Pendahuluan}

Reyog Ponorogo adalah sebuah pertunjukan tarian yang dinamis dan atraktif. Dalam bukunya, (Jazuli, 1994)menjelaskan bahwa bentuk merupakan wujud dari sebuah tarian, sebuah tarian akan menemukan bentuk seninya apabila pengalaman batin pencipta maupun penarinya dapat menyatu dengan pengalaman lahirnya. Hal ini dapat dimaksudkan agar audience dapat tergerak dan bergetar emosinya atau dengan kata yang lebih sederhana penonton dapat terkesan setelah menyaksikan pertunjukan tari tersebut.

Obyog atau obyogan diartikan dalam kamus bahasa Jawa adalah bebarengan nyambut gawe dengan pengertian yang sama dalam bahasa Indonesia mengerjakan pekerjaan bersamasama (Kumorohadi, Reyog Obyogan Perubahan dan Keberlanjutan Cara Penyajian dalam Pertunjukan Reyog Ponorogo, 2004, hal. 23-24). Istilah obyog juga disebut dalam buku pedoman sebagai nama untuk salah satu permainan musik sebagai iringan tari barongan atau tabuhan menjelang pentas (Ponorogo, Pemkab, 1993). Salah satu motivasi ramainya pertunjukkan Reyog obyogan adalah adanya interaksi dan komunikasi antara penonton dengan pemain. Interaksi ini dapat berupa sapaan, mengajak menari bersama bahkan memberikan uang atau biasa disebut dengan saweran. Konco Reyog adalah sebutan bagi orang-orang yang antusias dan serta ikut menjadi bagian dari sebuah pertunjukkan Reyog obyogan meskipun bukan bagian resmi dari tim Reyog yang sedang bermain.

Setiap pertunjukkan Reyog selalu ada dan menjadi salah satu unsur utama disamping dadak merak itu sendiri yaitu Penari jathil. Jathil dalam kesenian Reyog Ponorogo dalam sejarahnya sejak awal adalah dari kaum laki-laki (disini ada yang mengkaitkannya dengan gemblak). Namun terlepas perdebatan asal-muasal pelaku jathil ketika masih diperankan oleh 


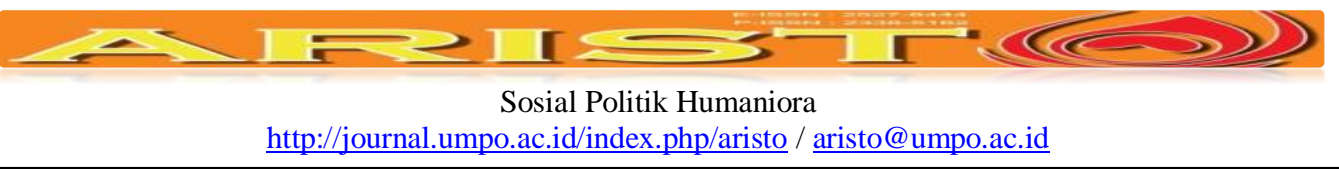

kaum laki-laki (penari jathil netral maupun gemblak), yang jelas semua tokoh menyatakan bahwa pementasan tari jathil merupakan simbolisasi dari olah kaprajuritan yang secara jelas menggambarkan perilaku dan sikap yang tegas, tangkas, dan cekatan yang kesemuanya mengarah pada ketrampilan menghadapi musuh yang menyerang (Kurnianto, LAPORAN HASIL PENELITIAN.PENCITRAAN PEREMPUAN DALAM KASUS PERUBAHAN PELAKU JATHIL DARI LAKI-LAKI MENJADI PEREMPUAN PADA SENI REYOG PONOROGO, 2007, hal. 34)

Budaya selalu mempunyai karakteristik yang sama dalam menjaga eksistensi dan keberlanjutan sebuah budaya itu sendiri. Hal ini tidak terlepas dari sebuah proses komunkasi yang berjalan didalamnya. Karakteristik yang muncul dari budaya-budaya tersebut adalah budaya itu dipelajari (Culture is Learned),dibagikan(culture is shared), turun temurun dari generasi ke generasi (Culture is transmitted form generation to generation), berdasarkan symbol (Culture is based on symbol), sebuah proses dinamis ( culture is dynamic process)dan sebuah sistem yang terintegrasi (culture is an integrated system)(Larry A. Samovar, 2009, hal. 26-39).

Beberapa bentuk inilah yang menyebabkan budaya-budaya baru yang berasal dari luar budaya Ponorogo itu sendiri masuk dan menjadi bagian budaya dalam pertunjukkan reyog itu sendiri. Budaya-budaya tersebut sedemikian popular sehingga mudah dan muncul pada setiap pertunjukkan yang ada. Reyog dalam bentuk obyogan menjadi bahan kajian yang unik dalam sudut pandang seni tradisional yang terus berjuang dalam mempertahankan eksistensi dan keberlanjutan seni dan tradisi diantara kemajuan dan modernisitas jaman. Beberapa usaha yang dilakukan oleh reyog obyogan menjadi bahan yang sangat menarik jika dihubungkan dengan beberapa ciri atau usaha menjaga agar tetap menjadi salah satu pusat perhatian dalam setiap pertunjukkan. Diantaranya adalah dengan menambah perbendaharaan musik pengiring dengan memasukkan unsur lagu-lagu dangdut populer yang sedang digemari masyarakat pada saat sekarang. Penelitian ini merupakan sebuah penelitian dalam kajian bidang komunikasi budaya terutama dalam kajian komunikasi budaya pertunjukkan. Penelitian ini berangkat dari sebuah fenomena pertunjukkan reyog dalam bentuk reyog obyogan yang mulai mengalami pergeseran makna dengan adanya budaya populer dimasyarakat. Kita ketahui bersama bahwa reyog Ponorogo merupakan salah satu warisan budaya Indonesia yang menjadi ikon dalam wisata budaya Indonesia, tetapi pada kenyataannya pertunjukkan Reyog sendiri yang ada di daerah 


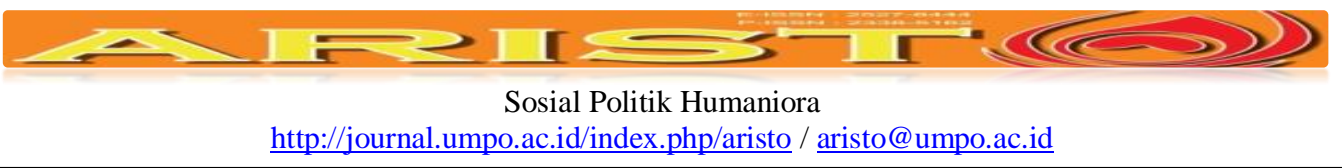

mengalami paradigma yang begitu kuat meskipun tidak begitu terasa, apalagi jika tinggal di Ponorogo sendiri sebagai holy Land Of Reyog.

Lebih jauh berbicara tentang budaya popular tentu tidak terlepas dari definisi tentang budaya itu sendiri dan pengertian dari popular yang secara terpisah. Selanjutnya budaya populer atau lebih dikenal dengan budaya pop bisa didefinisikan sesuai dengan pengertian-pengertian dari gabungan pengertian budaya dan pengertian populer. Penelitian tentang budaya populer dan reyog Ponorogo ini menjadi penting karena dalam pertunjukkan reyog Ponorogo sendiri mengalami perubahan-perubahan dari segi aspek komunikatif baik dari aspek visual atau tindakan komunikatif itu sendiri. Perlu diingat bahwa reyog sendiri merupakan sebuah pertunjukkan yang mengusung sebuah perjuangan Prabu Klana Sewandana dalam rangka memperjuangkan cintanya kepada Dewi Songgolangit. Dalam kisah inilah bisa kita lihat berbagai aspek komunikatif dalam urutan gerak, situasi dan symbol komunikatif yang dibangun didalamnya. Sedangkan fenomena yang terjadi pada saat ini adalah reyog mulai kehilangan makna komunikatifnya dengan masuknya budaya-budaya populer yang sedang tren dimasyarakat.

Makna yang ingin disampaikan seperti gagah dan cekatannya pasukan berkuda menjadi ter-reduksi dengan lenggak-lenggok penari jathil yang bergoyang layaknya penari jaipong serta tidak menggunakan ebleg atau kuda lumping. Garang dan beringasnya harimau sedikit berkurang dengan lemah dan lunglainya ketika berhadapan dengan penari jathil yang edreg didepannya. Melihat paradigma dan perkembangan inilah, fokus dalam penelitan ini adalah melihat lebih jauh dan mendalam bagaimana sebuah budaya populer yang sedang tren dimasyarakat mempengaruhi bentuk pertunjukkan dalam sebuah pementasan reyog ponorogo dalam bentuk obyogan. Tujuan utama dari penelitian ini juga menggali dan eksplorasi lebih jauh tentang perubahan-perubahan yang terjadi pada pertunjukkan reyog Ponorogo terutama dari aspek komunikatifnya, bentuk pertunjukkan serta makna-makna yang terkandung dalam setiap pertunjukka yang dipengaruhi oleh budaya populer dalam setiap detilnya.

\section{Metode}

Peneliti meneliti satu obyek yaitu seni pertunjukan Reyog Ponorogo tetapi hanya difokuskan pada saat pementasan seni itu sendiri. Jadi waktu yang diperlukan relatif lama dan panjang karena harus menunggu saat pementasan Reyog dengan formatObyogan yang tidak 


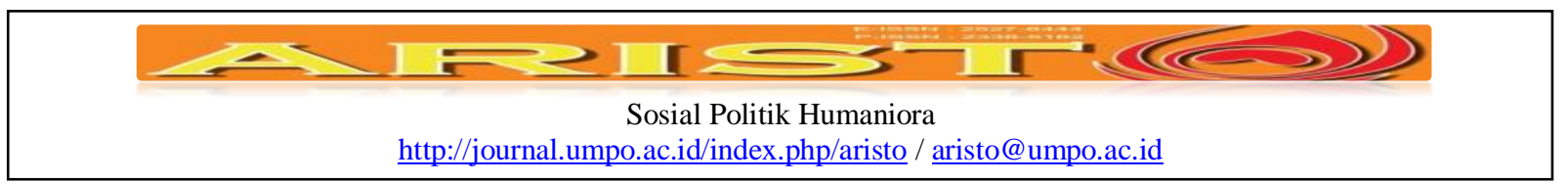

terjadwal secara pasti. Untuk lokasi penelitian di lingkupKabupaten Ponorogo. Data yang diperoleh dari beberapa lokasi penelitian teresebut kemudian dianalisis dan disajikan dalam bentuk deskripsi atau kata-kata.

Prosedur dari penelitian ini sudah masuk dalam kategori penelitian kualitatif dengan ciriciri sebagai berikut: (1) Ciri latar belakang alamiah, (2) Manusia sebagai alat instrumen, (3) metode kualitatif, (4) analisis data secara induktif, (5) teori dari dasar, (6) Bersifat deskriptif atau apa adanya, (7) Lebih mementingkan hasil daripada proses, (8) adanya batas yang ditentukan oleh fokus, (9) ada kriteria khusus untuk keabsahan data, (10) Desain bersifat semantara, (11) Hasil Peneltian dipentingkan dan disepakati bersama. (Moleong, 2000, hal. 4-8). Untuk penelitian ini difokuskan pada pertunjukan Reyog dengan format Obyogan. Dalam kenyataanya, Reyog Ponorogo terbagi menjadi duaversi besar yaitu versi Obyogan dan versi festival. Dalam beberapa bahasan penelitan ada yang menyebutnya sebagai Reyog jalanan, karena memang diadakan di jalanan, halaman rumah, lapangan, atau tempat-tempat tertentu yang dapat dijadikan tempat pertunjukan. Dua versi inilah yang menjadi unit analisis tentunya denga bantuan-bantuan dokumentasi yang terkait dengan penelitian ini.

Wawancara adalah percakapan dengan maksud tertentu yang dilakukan oleh dua pihak, pewawancara (interviewer) orang yang mengajukan wawancara atau pertanyaan dan orang yang diwawancarai (interviewie) yang memberikan jawaban atas pertanyaan itu (Moleong, 2000, hal. 135). Rencana Wawancara yang penulis gunakan adalah wawancara baku terbuka yang artinya adalah wawancara yang di lakukan dengan seperangkat baku dan obyek tahu bahwa ia menjadi nara sumber dari penelitian ini (Moleong, 2000, hal. 136). Wawancara ini dipilih karena ingin mendengar langsung penjelasan dari berbagai tokoh yang jadikan nara sumber dalam penelitian ini.

Nara sumber yang diwawancarai meliputi:

a) Seniman Reyog

Seniman Reyog Obyogan ini adalah beberapa warga yang menjadi pemain inti dalam setiap pertunjukkan Reyog. Seperti pemain yang sudah berprofesi sebagai penabuh kendang Reyog selama kurun waktu tertentu. Atau tokoh-tokoh lain yang berpenagruh pada pertunjukkan reyog ini diantaranya adalah Mbah Misdi sebagai sesepuh grup reyog Songgo Budoyo, Mbah Bikan sebagai sesepuh reyog Ponorogo yang tinggal di Pulung dan Bapak Marji, Seniman Reyog didalam dinas Pariwisata Kabupaten 


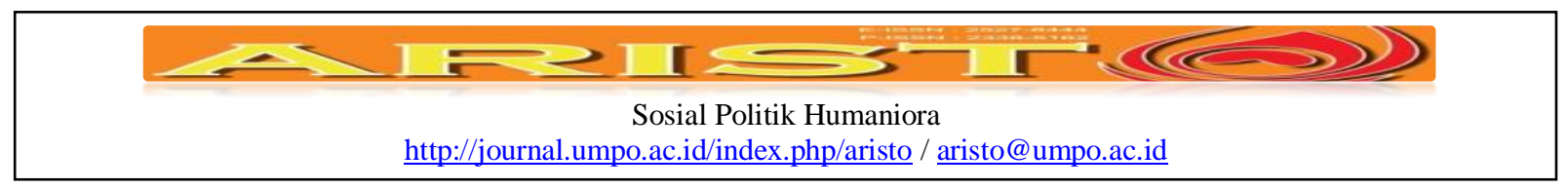

Ponorogo.

b) Pelaku seni Reyog Ponorogo

Pelaku seni Reyog ini adalah orang-orang yang menjadi pelaku atau seniman pada saat pertunjukkan Reyog. Para pelaku seni ini diambil secara acak dalam setiap kesempatan ketika pertunjukkan sedang berlangsung. Diantaranya adalah Nurul dan Santi sebagai penari Jathil, Eko "Badak" sebagai penari Dadak Merak, Hamzah sebagai Penari Bujangganong.

c) Konco Reyog

Konco Reyog ini adalah orang-orang yang menyaksikan langsung pertunjukkan Reyog dalam format Festival atau Obyogan. Dalam hal ini nara sumber ditemui pada saat sedangmenyaksikan pertunjukkan Reyog seperti Ibu Setyaningsih sebagai kepala Desa Ngilo-ilo,Bapak Hajiyanto selaku penaggap Reyog didesa Jati, Ngebel.

Teknik pemeriksaan keabsahan data yang digunakan dalam penelitian ini adalah triangulasi. Triangulasi adalah teknik pemeriksaan data yang memanfaatkan sesuatu yang lain di luar data itu, untuk keperluan pengecekan data atau sebagai pembanding terhadap data itu (Moleong, 2000, hal. 178). 4 macam triangulasi sebagai teknik pemeriksaan data yang memanfaatkan pengunaan sumber, metode, penyidik, dan teori. Triangulasi akan digunakan dalam penelitian ini adalah triangulasi metode yaitu pengecekan derajat kepercayaan penemuan hasil penelitian dengan beberapa teknik pengumpulan data (Moleong, 2000, hal. 178). Penelitian ini menggunakan observasi, wawancara, dan studi dokumen sebagai sumber data utama.

Observasi mutlak dilakukan dengan turun langsung dilapagan dengan mengamati setiap pertunjukkan yang bisa dijangkau dengan waktu atau jarak yang tidak terlalu jauh dari kota Ponorogo. Observasi ini merupakan hal wajib jika ingin menggali lebih dalam dan memahami dengan akurat setiap detil perubahan yang terjadi pada setiap pertunjukkan reyog yang ada. Karena menurut penulis, setiap pertunjukkan reyog dari satu tempat ke tempat lain mengalami perbedaan meskipun tidak terlalu kelihatan.

Dengan observasi langsung, penulis mendapatkan kesempatan bertanya langsung dan menggali informasi lebih dalam dilokasi pertunjukkan reyog Obyogan. metode ini terbukti cukup ampuh dalam mendekatkan penulis kepada setiap element pertunjukkan baik dari sisi pemain, tokoh masyarakat atau konco reyog yang hadir. Wawancara merupakan hal yang enting dan harus dilakukan jika kita ingin tuisan yang kita hadirkan mempunyai kedalaman cerita, sudut 


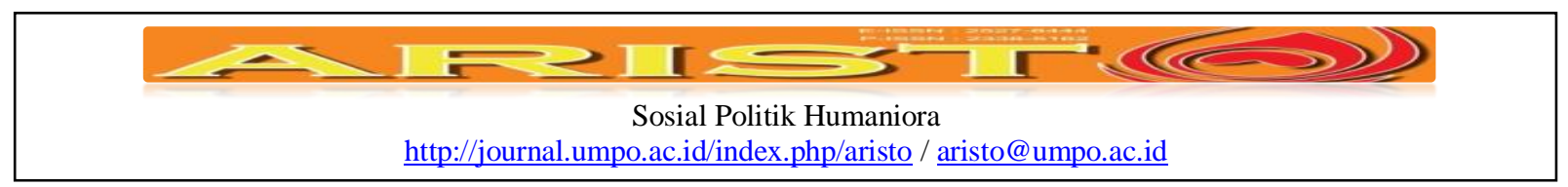

pandang yang berbeda yang tidak bisa kita gali hanya dengan pengamatan visual saja.

Studi dokumen berupa foto digunakan penulis sebagai penguat bentuk-bentuk kejadian yang ada pada pertunjukkan reyog obyogan. penanda-penanda yang ada terkadang tidak bisa kita gambarkan hanya cukup dengan kata-kata saja. terkadang pembaca juga mempunyai intepretasi yang berbeda terhadap sebuah bentuk komunikasi visual berupa gambar foto. Gambar foto sebagai data utama juga sebagai bukti kuat bahwa sebuah fenomena sedang terjadi dan menjadi sebuah bukti sejarah yang dapat disebarkan dan dimaknai secara luas dikemudian hari.

\section{Budaya Populer}

Kata "pop" diambil dari kata "populer". Williams memberikan empat makna yakni: (1) banyak disukai orang; (2) jenis kerja rendahan; (3) karya yang dilakukan untuk menyenangkan orang; (4) budaya yang memang dibuat oleh orang untuk dirinya sendiri (Williams, 1983, hal. 237) Budaya populer atau budaya pop merupakan sebuah konsepsi yang tidak berbentuk dan sulit untuk dipastikan secara nyata, tetapi didalamnya mencakup luas sekali terutama dalam cakupan budaya dari dunia perfilman sampai artikel koran, dari desain permainan elektronik sampai kostum pemain dalam film imajiner. Tetapi dalam budaya populer lebih mengarah pada budaya media, yang didalamnya terdapat media masa sebagai saluran informasinya seperti radio, koran, televisi, film serta termsuk didalamnya email dan website.(Katie Milestone, 2012, hal. 2)

Pandangan atau perspektif yang sedikit berbeda mengenai budaya pop adalah budaya yang dipandang dari perspektif tinggi (high atau elite) dan budaya rakyat jelata (folk culture). Seperti halnya dengan kenyataan dalam hal makanan kita sehari-hari yaitu daging lapis dalam budaya tinggi masuk kedalam makanan favorit para bangsawan sedangkan steak daging atau lebih dikenal dengan steak hotplate menjadi budaya populer. Semua hal tersebut merupakan budaya yang kita kenal sehari-hari dengan budaya makanan atau kuliner yang selalu mengelilingi kita dan kita rasakan sehari-hari. High culture seperti halnya pakaian yang melekat dan menjadi identitas kita dalam sebuah acara. Sedangkan budaya tradisioal merupakan budaya warisan yang ditinggalkan atau budaya yang dipegang tegus oleh orang-orang tua kita yang dimungkinkan merupakan budaya populer pada jamannya. Budaya populer merupakan budaya yang sedang trend atau populer pada saat sekarang. (Bruce David Forbes, 2005, hal. 2).

Menurut Ben Agger, pemikiran tentang budaya popular dapat dikelompokan menjadi yaitu:

Oki Cahyo Nugroho, Hadi Purwanir. Budaya Populer dalam pertunjukkan reyog Obyogan / 02 / Vol.5. No. 1. Tahun 2017 


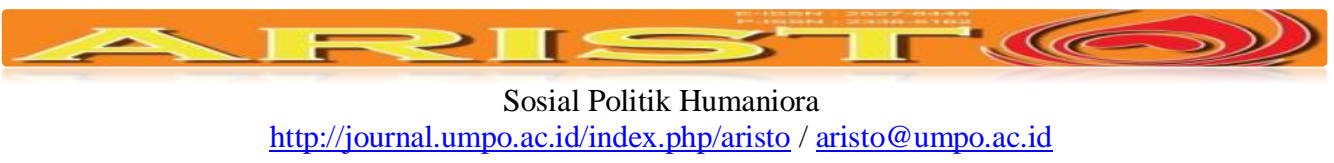

1. Budaya dibangun berdasarkan kesenangan namun tidak substansial dan mengentaskan orang dari kejenuhan kerja sepanjang hari.

2. Kebudayaan popular menhancurkan kebudayaan tradisional.

3. Kebudayaan menjadi masalah besar dalam pandangan ekonomi kapitalis Marx.

4. Kebudayaan popular merupakan budaya yang menetes dari atas. (Bungin, 2008, hal. 100)

\section{Hasil dan Pembahasan}

\section{Budaya Populer dalam Pertunjukkan reyog Obyogan}

\section{Kostum}

Reyog ponorogo merupakan sebuah kesenian yang berangkat dari sebuah mitos yang dibangun di masyarakat ponorogo. Cerita tentang sejarah reyog sendiri meskipun ada beberapa versi dalam masyarakat, tetapi beberapa ahli reyog dan budayawan ponorogo sepakat bahwa reyog ponorogo dibangun diatas mitos kerajaan Bantarangin. mitos reyog Bantarangin sendiri merupakan sebuah mitos dimana pada jaman sekitar abad ke 14 berdiri kerajaan Bantarangin di wilayah Somoroto, barat kota Ponorogo atau beberapa budayawan menyebutnya sebagai Kutho Kulon.

Mitos Bantarangin sendiri mempunyai cerita bahwa rajanya yang bernama Prabu Klana sewandana ingin melamar salah satu putri dari kerajaan Kediri yang bernama Dewi Songgolangit. Raja KlanaSewandana berangkat dari kerajaan Bantarangin diringi oleh Patih Bujangganong, Pasukan berkuda atau Jathil dan penthul Potro dan penthul Tembem. Tetapi ditengah perjalanan dihadang oleh kawanan harimau yang sedag bermain dengan merak diatas kepala harimau. Singkat cerita prabu Klanasewandana dapat mengalahkan kawanan harimau dan merak ini kemudian menjadi pengikutnya dalam usahanya melamar Dewi Songgolangit.

Melihat mitos ini dan mengaitkannya dengan pertunjukkan reyog sekarang maka akan didapat sebuah benang merah yang terhubung dalam hal kostum situ sendiri. Hal ini dapat kita lihat pada kostum terutama pada penari jathil yang merupakan sebuah representasi dari pasukan berkuda. Pasukan berkuda dalam pertunjukkan reyog diibaratkan sebuah kelompok pasukan yang sigap dan cekatan. Jika kita bandingkan dengan reyog dalam bentuk festival, maka pasukan berkuda atau penari jathil dalam pertunjukkan reyog obyogan akan sangat berbeda.

Pada penari-penari jathil pada pertunjukkan reyog festival, para peanri memakai pakaian kemeja lengan panjang dengan warna putih dan memakai ebleg atau kuda lumping dalam setiap pertunjukkannya. Hal ini berbeda dengan penari jathil yang ada pada pertunjukkan reyog 


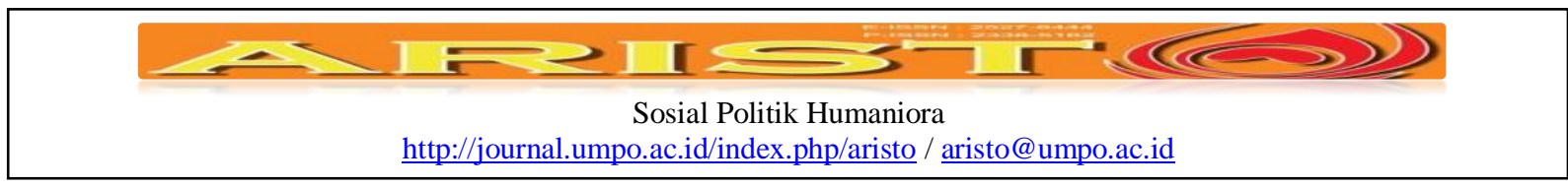

obyogan. Para penari obyogan memakai pakaian yag berwarna-warni dan transparan. Para penari ini menyebut pakaian ini sebagai 'broklat'. Alasan mengenai pakaian ini pun beragan, tetapi satu yang pasti adalah pakaian ini sedang tren atau sering dipakai pada saat acara formal terutama pada acara pengantin jawa. Warna-warni pada kostum penari jathil pada saat sekarang sudah dinggap wajar karena sebagian besar pertunjukkan reyog obyogan menggunakan kostum model seperti ini dalam setiap pertunjukkannya.

Kostum ini lebih kelihatan pada kostum bagian atas dari penari-penari Jathil ini. Kostum bagian bawah masih mempertahankan bentuk sebelumnya dengan jarik atau sampur. Hal ini merupakan sebuah bentuk perubahan-perubahan yang mengarah pada bentuk sebuah budaya dimana bagian-bagian tertentu kemudian digatnti atau pelan-pelan berubah sesuai dengan yang diinginkan masyrakat pada saat itu.

\section{a. Baju berwarna dan transparan}

Pertunjukkan reyog dalam format obyogan merupakan pertunjukkan yang sangat erat kaitannya dengan apa yang disukai dalam masyarakat poorogo pada saat itu. Dengan demikian, reyog dalam bentuk obyogan ini merupakan sebuah cerminan dimana sebuah kesenian yang tradisional dapat berpadu dengan sebuah fenomena budaya masa kini yang sedang disukai masyarakat. Bentuk dari sebuah budaya populer yang sedang merebak pada sebuah tatanan masyarakat ini sangat dipengaruhi oleh tingkat pendidikan, interaksi sosial dan politik diamana budaya tersebut berada.

Salah satu bentuk budaya populer dalam pertunjukkan reyog ini adalah yang terdapat pada kostum bagian atas dari penari jathil obyogan. penari-penari jathil ini sangat berbeda dengan penari-peanri jathil pada pertunjukkan reyog festival. Jika penari jathil festival memakai kemeja dengan warna putih dan tidak tranasparan maka penari-penari jathil pada pertunjukkan reyog obyogan ini memakai baju atau kemeja dengan warna yang berbeda dan transparan. Jika dilihat secara luas, maka pemakaian kemeja ini adalah sebuah bentuk dimana bentuk kemeja transparan ini sedang populer terutama pada masyarakat jawa sekarang. Kemeja atau setelan baju tradisonal pada masyrakat jawa disebut sebagai kebaya merupakan pakaian khas yang telah mengalami beberapa modifikasi dalam beberapa bentuk dan keperluan dalam aktifitasnya. Pakaian ini merupakan sebuah bentuk pula dimana masyarakat berkembang dengan pesat dalam mengikuti trend dan kemajuan jaman jika tidak ingin dikatakan sebagai masyarakat yang 


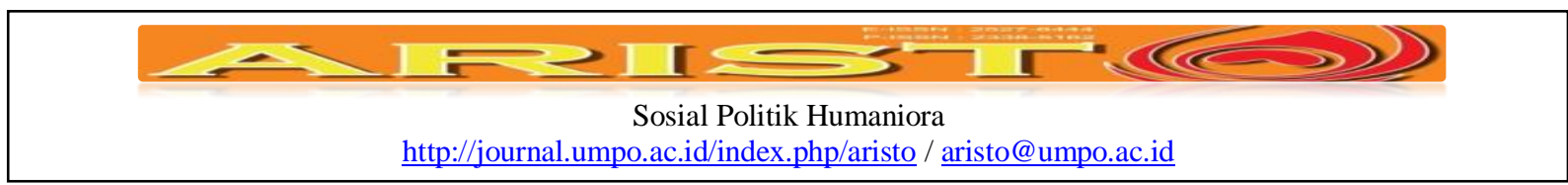

ketinggalan jaman. Dengan demikian pertunjukkan reyog dalam bentuk obyogan tetap menjadi sebuah primadona dengan penampilan penari jathil yang atraktif dan kostum yang up to date.

Bentuk kemeja ini merupakan sebuah evolusi dimana trend dalam fashion juga merambah dan masuk kedalam sebuah pertunjukkan rakyat dengan konsep tradisional yang kental. Dalam beberapa kesempatan wawancara, peneliti menemukan alasan yang kuat kenapa para pelaku - pelaku seni tersebut harus selalu up to date terutama dalam kostum ini. Alasan yang kuat adalah faktor ekonomi. Faktor ekonomi inilah yang menjadi sebuah alasan utama yang berhubungan langsung dengan banyaknya tanggapan yang seiring dengan popularitas dari jathiljathil tersebut. Dengan demikian, para penari juga harus tetap berpakaian yang sedang tren atau banyak disukai di masyarakat pada saat itu. Cukup sulit menghubungkan antara fenomena budaya populer dengan sebuah kesenian daerah dimana prinsip dari sebuah penelitian budaya populer ini bertumpu pada sebuah kondisi masyaratkat yang cukup mejemuk dan beragam. Kondisi masyarakat inilah yang terkdadang membaut bingung dari sisi orang yang melihat dan sebuah fenomena budaya populer dalam pertunjukkan daerah khususnya reyog obyogan.

Para penari ini juga tidak kesulitan dalam mengembangkan mode dan warna baju seperti yang disenangi dalam berbagai pertunjukkan dalam masyarakat, karena ada banyak fasilitas yang mendukung. Beberapa fasilitas yang mendukung berkembangnya kostum dalam tarian tradisional ini adalah adanya sanggar-sanggar tari atau salon - salon yang mengkhususkan diri dalam mempersiapkan kostum yang akan diapakai. Hal ini tidak terlepas pula dengan adanya penagaruh dari pesatnya budaya di ponorogo terkait dengan tradisi manten atau pengantin yang selalu berkembang dengan kreasi - kreasi baru, khususnya dalam trend mode baju.

Gambar 1. Penari Jathil pada pertunjukkan reyog obyogan di Kecamatan Slahung yang memakai pakaian berwarna-warni dan transparan.

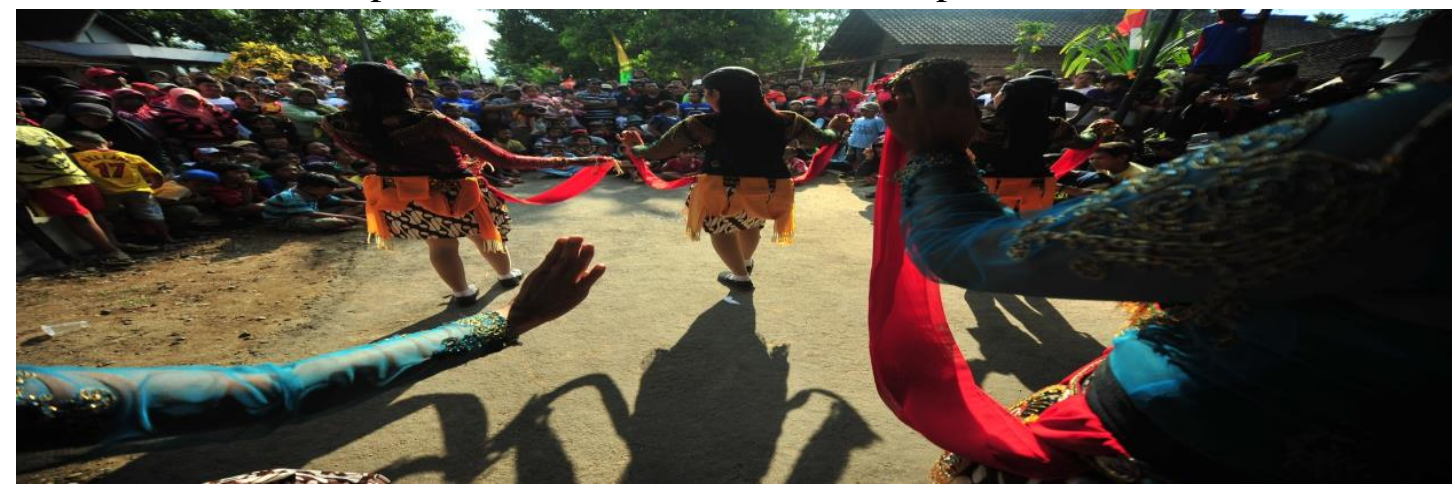

Sumber: diolah dari dokumentasi peneliti.

Oki Cahyo Nugroho, Hadi Purwanir. Budaya Populer dalam pertunjukkan reyog Obyogan / 02 / Vol.5. No. 1. Tahun 2017 


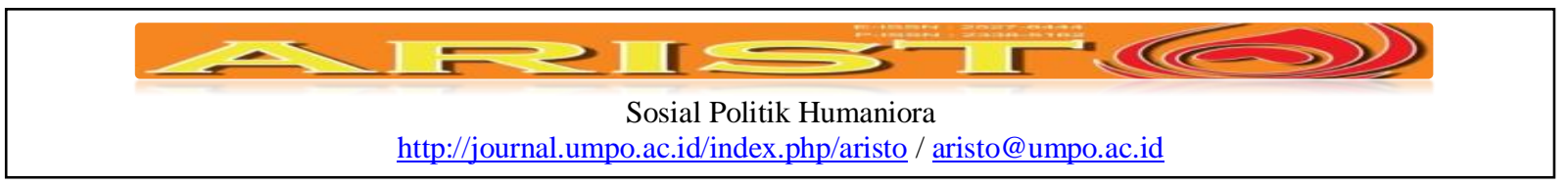

\section{b.Sepatu Kerja Kantor}

Melihat pertunjukkan reyog dengan format obyogan layaknya melihat sebuah miniature masyarakat Ponorogo yang dikemas dalam sebuah pertunjukkan rakyat dengan konsep kekeuargaan yang kuat. Konsep-konsep ini merupakan inti dari pertunjukkanreyog dalam bentuk obyogan yang sudah turun temurun dalam masyarakat ponorogo sehingga sangat kuat dalam akar budaya ponorogo.

Hal unik lagi yang dapat kita temui dalam pertunjukkan reyog obyogan adalah penggunaan sepatu kerja kantor. Hal ini menjadi salah satu bentuk yang unik karena sepatu kerja ini sangat populer dalam petunjukkan reyog terutama obyogan. sepatu kerja kantor dengan nuansa formal masuk dalam pertunjukkan reyog obyogan dengan kesan yang informal, santai dan lebih banyak berada dilapangan. Jika kita rasakan, pemakaian sepatu kerja kantor ini tidaklah sesuai dengan konsep reyog obyogan yang berada di lapangan dengan mobilisasi yang cukup tinggi. Konsep sepatu kerja kantor ini juga tidak terlalu sesuai dengan kondisi luar ruangan yang cukup panas dan terik serta debu dan kotoran yang pada akhirnya menempel pada sepatu ini. Disamping itu, pergerakan tari dengan sepatu ini juga mengalami keterbatasan karena bentuk dan fungsi sepatu ini memang bukan untuk menari atau aktifitas diluar ruangan dengan banyak gerak. Hal yang berbeda diungkapkan oleh para pelaku atau para penari jathil ini. Mereka beranggapan bahwa dengan memakai sepatu ini layaknya prajurit berkuda yang memakai sepatu dan aksesoris layaknya pasukan atau orang yang sedang naik kuda. Disamping itu, sepatu ini sebagai simbol status sosial dalam menari pada pertunjukkan reyog dimana seluruh penari dalam reyog obyogan tidak ada yang memakai sepatu.

Konsep sepatu kantor ini juga sebagai pelindung ketika menari dalam sebuah arena pertunjukkan yang diadakan diluar ruangan atau lapangan. Tidak jarang, pertunjukkan ini diselenggarakan dijalan, halaman rumah, bahkan kebun atau tegalan yang ditata sedemikian rupa sehingga memungkinkan diadakan sebuah pertunjukkan reyog obyogan ini. Menurut para penari juga, hanya sepatu ini yang sesuai mewakili setiap kondisi dimana mereka menari. Sepatu ini pula yang paing mudah ditemui dan dimanfaatkan selain sebagai sepatu sekolah atau sepatu kerja harian para jathil tersebut jika mereka masih sekolah atau sedang bekerja pada sebuah instansi baik swasta maupun pemerintahan.

Oki Cahyo Nugroho, Hadi Purwanir. Budaya Populer dalam pertunjukkan reyog Obyogan / 02 / Vol.5. No. 1. Tahun 2017 


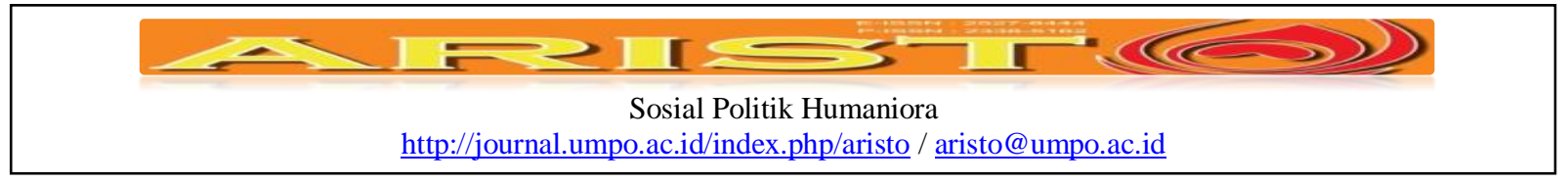

Gambar 2. Penari jathil pada pertunjukkan reyog obyogan dengan sepatu formal dan stocking.

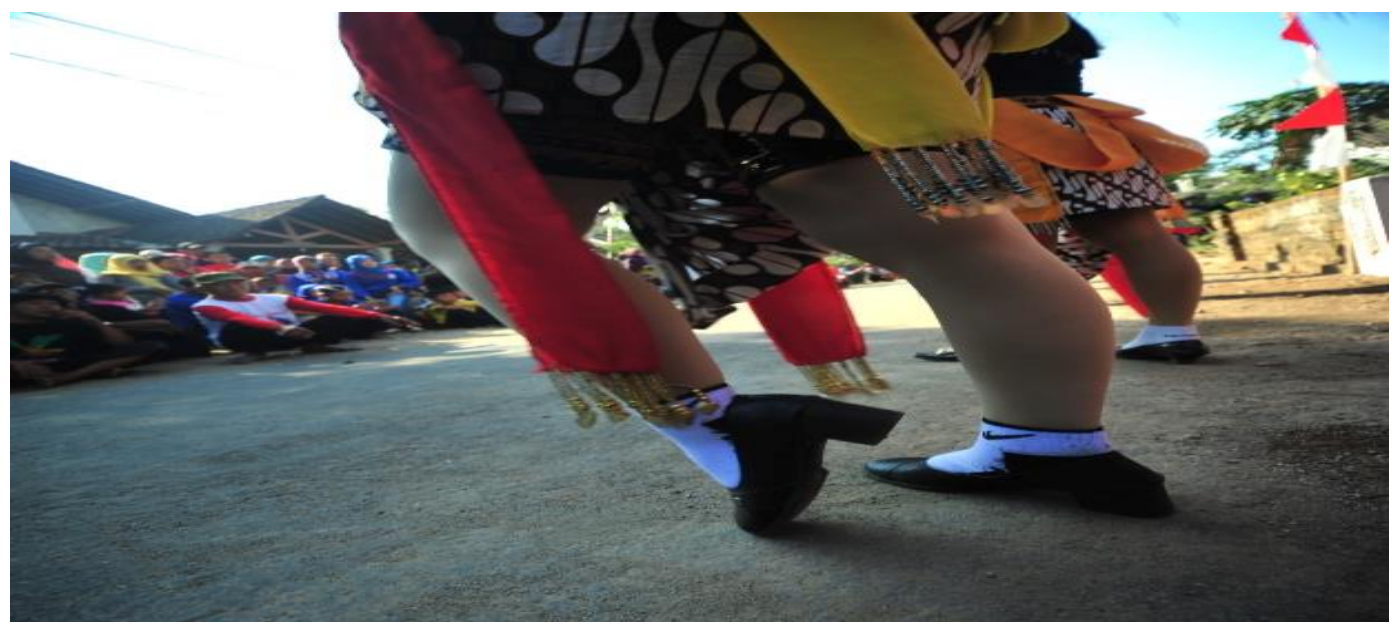

Sumber: diolah dari dokumentasi peneliti.

\section{Perangkat pertunjukkan}

Reyog Ponorogo merupakan sebuah pertunjukkan yang menceritakan sebuah cerita tertentu. Dalam menceritakan sebuah mitos yang mengirinya, dibutuhkan perangkat yang dapat membantu dalam penyampaian pesan, sehingga tidak timbul bias dalam penyampaian pesannya yang dimaksud. Hal ini dapat kita lihat dalam bentuk pertunjukkan reyog obyogan yang sering kita jumpai dalam pertunjukkan reyog terutama dalam pertunjukkan reyog obyogan. pertunjukkan reyog obyogan sering kali menginggalkan perangkat pertunjukkan demi mengejar pupularitas dalam pertunjukkannya. Perangkat yang sering ditinggalkan dalam sebuah pertunjukkan adalah ebleg, atau kuda lumping yang dipakai oleh peanri jathil. Penari jathil merupakan representasi dari pasukan berkuda yang tidak lengkap jika tanpa ebleg atau kuda lumpingnya. Kuda lumping yang terbuat dari bambu dengan warna putih ini merupakan sebuah bentuk dari komunikasi budaya yang mencerminkan ciri seorang pasukan berkuda yang cekatan dan sigap.

Fenomena yang terjadi dalam pertunjukkan reyog obyogan adalah para penari jathil ini enggan memakai perangkat pertunjukkan kuda lumping atau disebut dengan ebleg ini. Menurut pengakuan beberapa penari jathil yang ditemui mengatakan bahwa sangat susah menari jika memakai ebleg dan penggunaan ebleg hanya untuk menari festival saja, disamping itu ebleg tidak populer dalam pertujukkan reyog dalam bentuk obyogan. hal ini dapat dibuktikan dari 


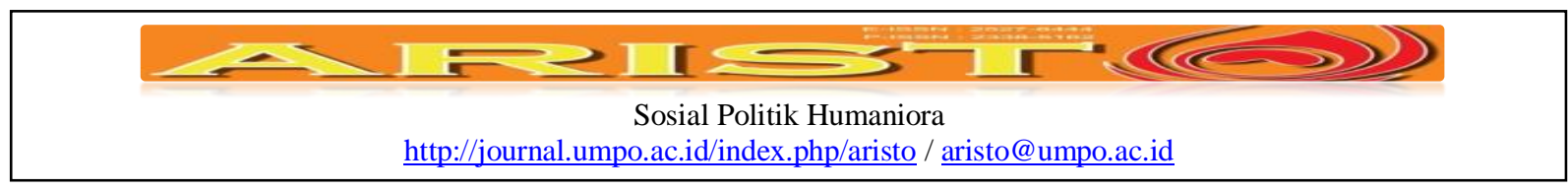

sebagian besar pertunjukkan reyog obyogan tidak memakai ebleg atau kuda lumping. Jika pun ada yang memakai kuda lumping hanya satu atau dua pertunjukkan saja. Salah satu pertunjukkan yang masih mempertahankan penari jathil dengan kuda lumping adalah pertunjukkan reyog yang di desa Plunturan Pulung. Menurut sesepuh reyog yang ada disana Mbah Bikan, reyog desa Plunturan pulung akan tetap mempertahankan bentuk reyog obyogan dengan perangkat pertunjukkan lengkap, tidak peduli dengan yang sedang populer pada saat ini, atau yang sedang disenangi masyarakat pada saat sekarang. Dengan demikian, pertunjukkan reyog dari desa Plunturan Pulung ini tidak terlalu populer dalam pertunjukkan reyog obyogan karena jarang yang 'nanggap'.

Perangkat pertunjukkan yang sering dimodifikasi dalam penampilannya adalah ebleg, topeng bujangganong bahkan dadak merak itu sendiri. Artinya, para penari ini akan melepas beberapa perangkat dalam sebuah pertunjukkan yang sedang berlangsung. Perangkat-perangkat ini dilepaskan dalam sebuah pertunjukkan dan dapat kita jumpai pada hampir seluruh pertunjukkan reyog yang ada. Hal ini pn tidak menjadi sebuah masalah bagi para penari dan dapat diterima dalam sebuah kondisi pementasan. Hal yang sering kita jumpai adalah hilangnya ebleg pada penari jathil dalam hampir setiap pertunjukkan reyog obyogan. Hal lain yang dapat kita temui adalah penari Bujangganong melepaskan topengnya dan menari atau melakukan atraksi tanpa topeng. Hal yang tidak mungkin dilakukan dalam pertunjukkan reyog festival, karena hal ini akan mengurangi bahkan akan didiskualifikasi. Penari-penari Bujangganong akan melepaskan topengnya dalam sebuah adegan terutama dalam edreg.

Gambar 1. Penari Jathil pada pertunjukkan reyog yang tidak memakai kuda lumping atau ebleg

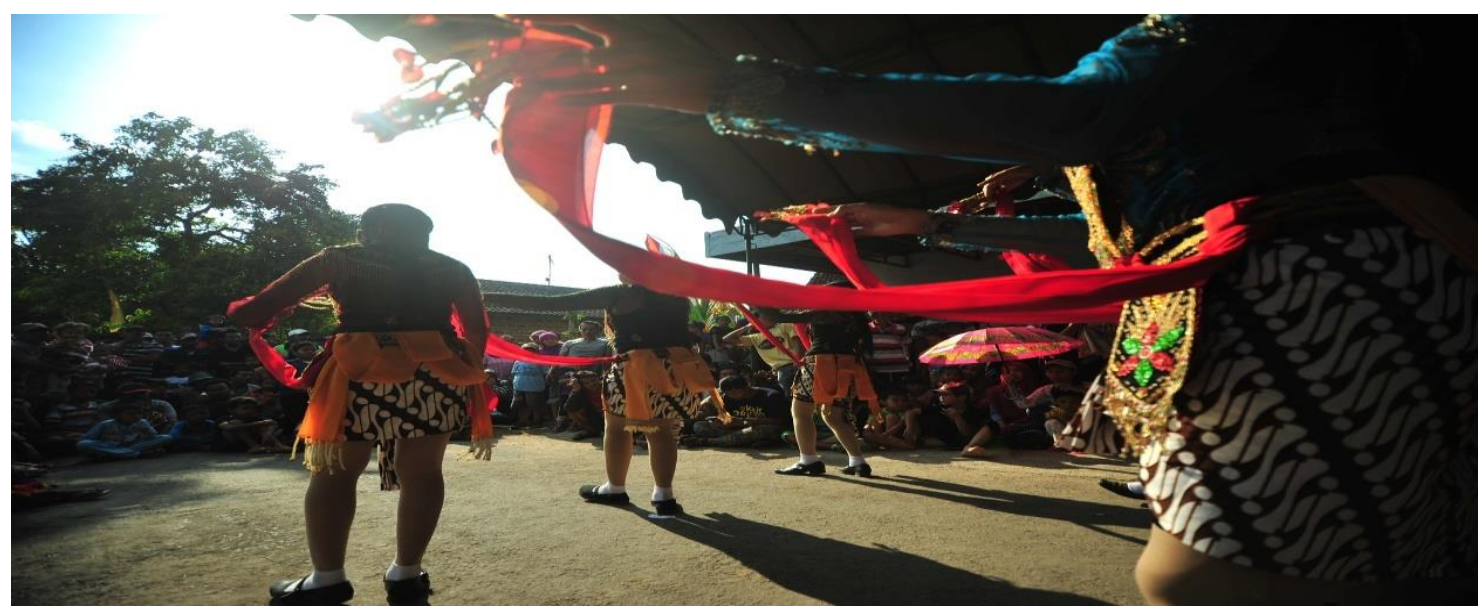

Sumber: diolah dari dokumentasi peneliti

Oki Cahyo Nugroho, Hadi Purwanir. Budaya Populer dalam pertunjukkan reyog Obyogan / 02 / Vol.5. No. 1. Tahun 2017 


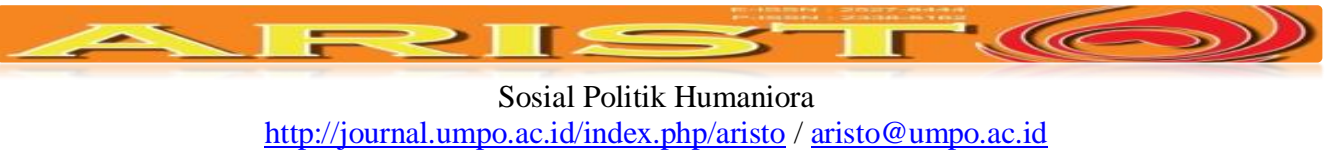

\section{Gending atau tembang}

Reyog Ponorogo dalam pertunjukkannya merupakan sebuah pertunjukkan dengan daya adaptasi yang luar biasa dalam setiap pertunjukkannya. Pertunjukkan reyog obyogan ini merupakan sebuah usaha dalam usaha tetap bertahan dalam gempuran globalisasi dan kemajuan jaman. Terutama dalam usaha beradaptasi dengan para konco reyog yang dinamis dalam interaksi sosialnya. Salah satu usaha dalam mengikuti kemajuan jaman ini adalah dengan belajar gending atau lagu yang sering diperdengarkan di masyarakat. Lagu atau gending yang sering dipedengarkan ini bukan lagu pop modern yang digemari anak muda, tetapi lebih spesifik lagu atau tembang yang dipedengarkan lebih banyak lagu dengan nuansa tradisional yang disebut campursari.

Lagu atau tembang campursari ini banyak diadaptasi dalam bentuk pertunjukkan reyog obyogan dengan gamelan reyog yang terbatas dalam nada, tidak seperti gamelan karawitan yang lengkap dalam nada dan iramanya. Gamelan reyog hanya sebatas kendang, kempul, kethuk dan kenong serta angklung. Dengan demikian kemampuan seniman reyog dalam usahanya mengadaptasi lagu memerlukan pengetahuan yang cukup mengenai popularitas dari lagu yang akan dibawakan. Popularitas lagu yang menjadi favorit di masyarakat dapat dilihat dari intensitas putar dalam siaran radio atau jumlah kaset CD atau DVD yang diperjualbelikan di masyarakat.

Dalam pengamatan yang dilakukan pada beberapa pertunjukkan, gending atau tembang yang populer ini sering dipakai dalam adegan edreg. Edreg sendiri merupakan gerakan penari jathil dalam menggoda dadak merak. Lagu atau tembang yang digunakan sendiri cenderung rancak dengan ritme sedang. Contoh lagu yang sering dipakai dalam adegan ini adalah 'walang kekek' atau sekarang yang lagi disukai adalah 'Kanggo Riko'. Tidak cuma berhenti pada adapatasi lagu saja, para pemain khususnya pemain kendang juga meningkatkan kemampuannya dalam memainkan musik ini sesuai atau bahkan lebih dibanding dengan lagu aslinya. Sebagai penabuh kendang, kemampuan dalam memainkan kendang tidak terbatas hanya pada gendinggending pakem yang ada pada pertunjukkan reyog seperti Kebogiro, Ponoragan atau Sampak. Kemampuan dalam memainkan lagu atau tembang yang 'kekinian' juga menjadi tuntutan dalam sebuah pertunjukkan terutama dalam pertunjukkan reyog obyogan.

Salah satu bentuk kemampuan ini adalah kemampuan memainkan kendang layaknya pemain kendang pada pertunjukkan tari jaipong. Pemain kendang pada pertunjukkan reyog akan 


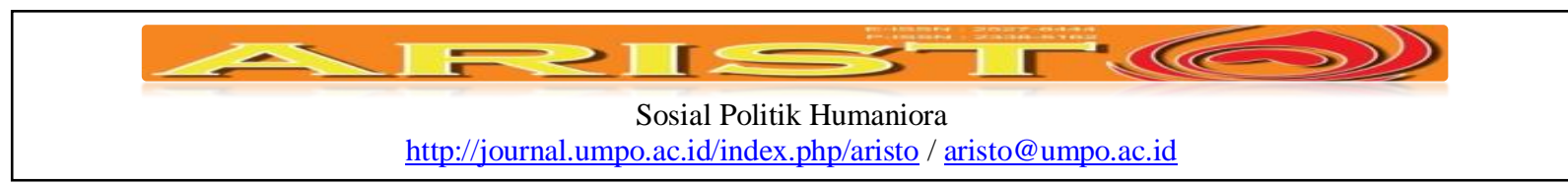

berusaha memainkan kendangnya layaknya pertunjukkan tari jaipong, tetapi yang membedakan dalam hal ini adalah jenis kendangnya. Jika dalam pertunjukkan tari jaipong lebih dari satu kendang, maka pertunjukkan reyog hanya akan menggunakan hanya satu kendang saja. Dengan adanya satu kendang inilah yang menarik dalam pertunjukkan reyog obyogan. Pertunjukkan reyog obyogan terutama dalam usahanya beradaptasi dengan lagu atau tembang baru yaitu dengan memainkan kaki sebagai pengatur nada rendah dalam kendang itu sendiri. Nada tinggi dengan cara meletakkan kaki di tengah kendang dan untuk mendapatkan nada rendah kaki di geser kearah pinggir. Hal ini jika dimainkan dan dilakukan dengan latihan akan menciptakan komposisi nada yang menarik.

Kemampuan para pemian kendang dalam usahanya memainkan lagu dalam nuansa jaipong ini juga mempunyai keterbatasan. Yang pertama adalah kendang yang digunakan merupakan kendang reyog yang tidak dirancang untuk lagu jaipong. Ukuran kendang reyog jauh lebih besar dari ada ukuran kendang jaipong. Disamping itu, kendang reyog tidak dilengkapi dengan pangait kaki sehingga pemain kendang tidak bisa lama dalam memainkan nada.

Gambar 2. Pemain kendang dalam pertunjukkan reyog obyog menggunakan kaki untuk mendapatkan efek nada yang diinginkan

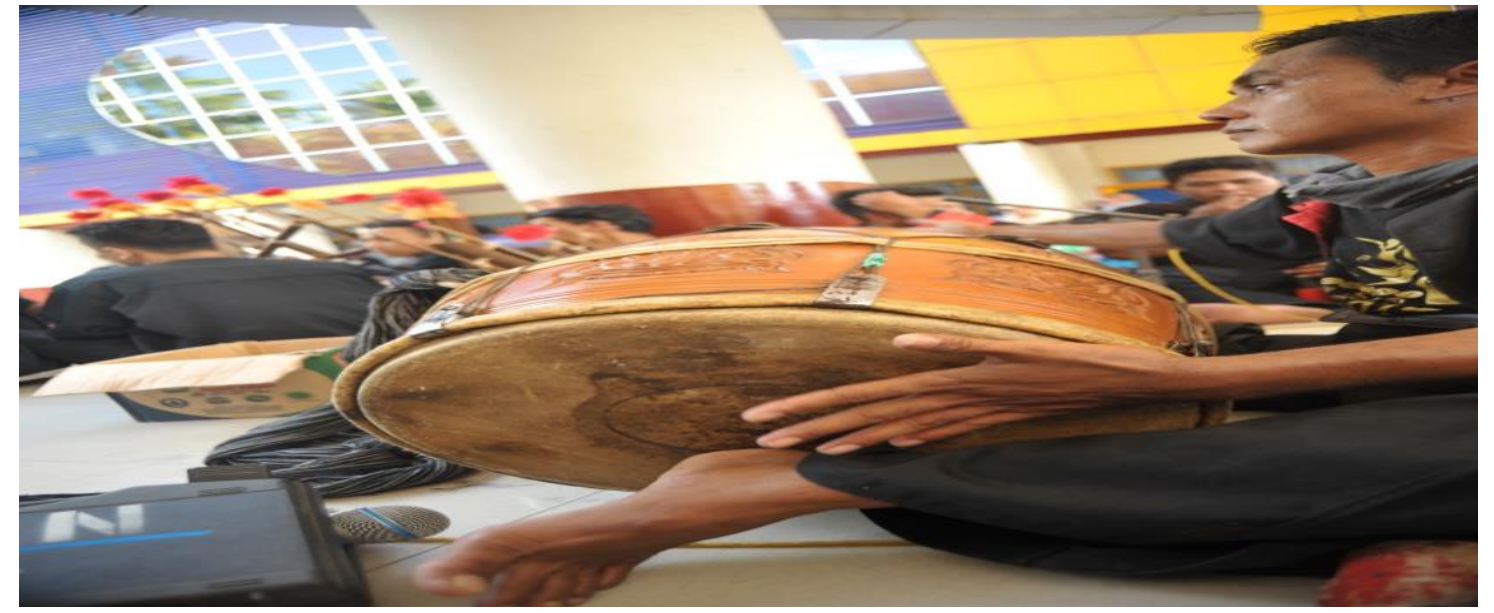

Sumber: diolah dari dokumentasi peneliti

\section{Drama Pertunjukkan}

Dalam pertunjukkan reyog khususny apertunjukkan reyog obyogan, tidak lepas dari sebuah bentuk-bentuk pertujukkan yang sangat berbeda dari pertunjukkan reyog festival. Setelah diperhatikan dan diamati dengan seksama, aksi-aksi yang dilakukan dalam pertunjukkan ini merupukan sebuah aksi yang sangat disukai oleh konco reyog dalam setiap pertunjukkan reyog yang berlangsung di Ponorogo. Aksi-aksi atau tindakan ini muncul sebagai inti dari pertunjukkan 


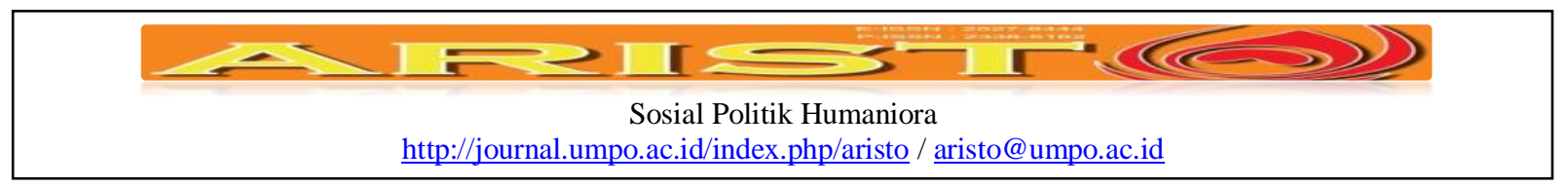

reyog tersebut dimana sangat dimungkinkan adanya interaksi antar pemain, pemain dan konco reyog. Tindakan-tindakan ini juga tidak bisa diprediksi sebelumnya sebagai sebuah scenario pertunjukkan yang telah tersetting dalam latihan, tetapi tetap menjadi sebuah bagian dari pertunjukkan reyog itu sendiri.

\section{a. Atraksi atau Guyonan}

Salah satu tindakan komunikatif dalam setiap pertunjukkan reyog obyogan adalah adanya peristiwa dimana konco reyog ikut berperan dalam sebuah pertunjukkan dan menari bersama dalam kalangan. Lebih spesifik lagi adalah pemain tersebut dapat menari layaknya penari-penari yang ada. Tetapi penari yang bisa atau dapat masuk kedalam kalangan hanyalah penari bujangganong dan penari dadak merak.

Penari Bujangganong merupakan sosok penari yang tangkas, cekatan dan lincah. Tidak ketinggalan pula tingkah lucu dan jenaka juga mengundang tawa dari konco reyog yang melihat pertunjukkan ini. Dengan demikian, dalam sebuah pertunjukkan reyog obyogan, para penari ini sering bertingkah layaknya pelawak yang sering kita lihat di televisi. Untuk menambah suasana menjadi lebih atraktif dan dinamis lagi, para pemain bujangganong ini menarik atau mengajak salah satu penonton masuk kedalam arena petunjukkan ini. Pakaian seadanya bukan menjadi halangan menari dalam sebuah pertunjukkan reyog obyogan ini.

Gambar 3.salah satu adegan dalam pertunjukkan reyoog seolah-olah sedang bertengkar

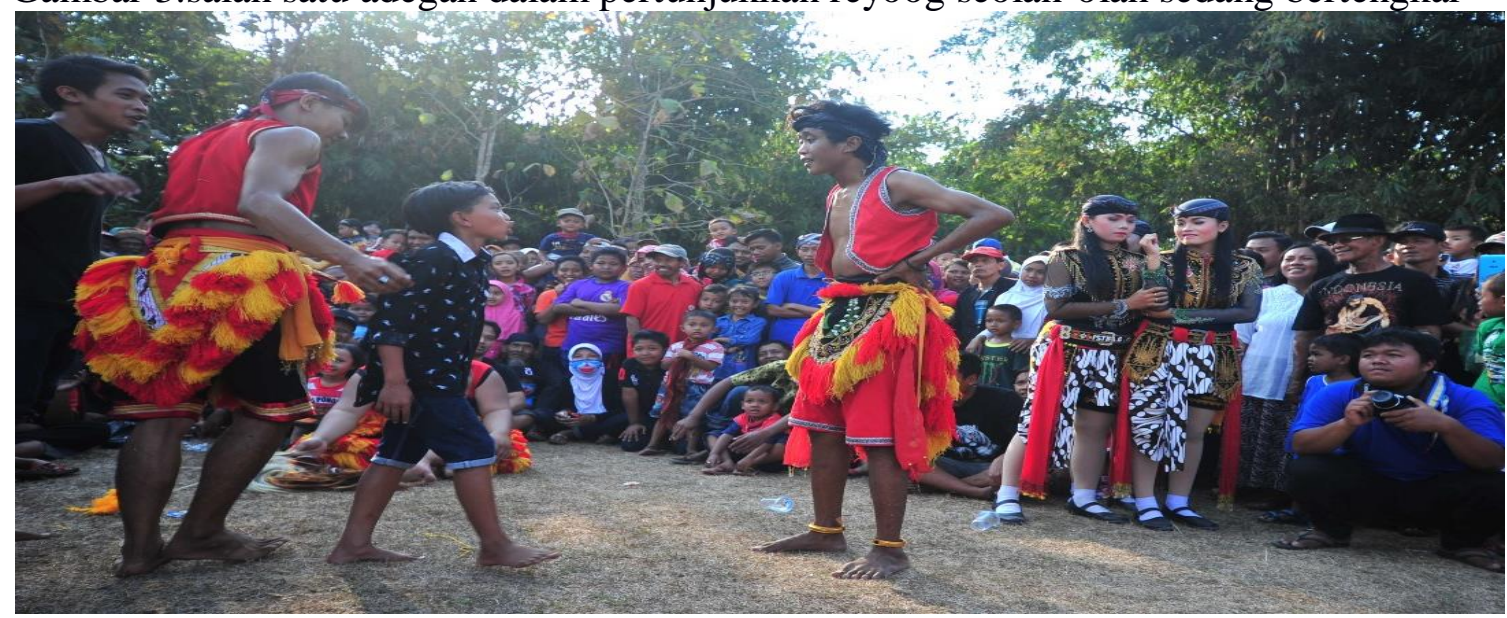

Sumber: diolah dari dokumentasi peneliti 


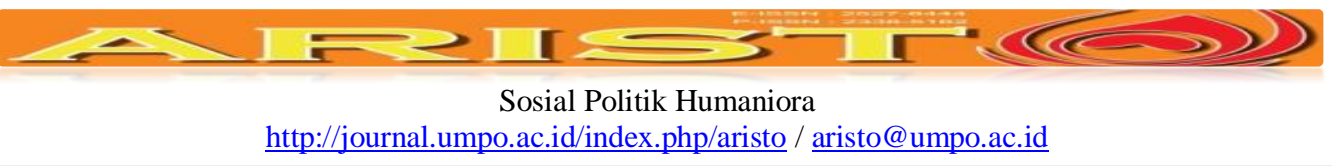

\section{b. Saweran}

Pertunjukan reyog obyogan terkadang mempunyai sebuah bentuk pertunjukkan yang unik. Bentuk pertunjukkan ini hanya ada kesenian rakyat dimana pemain dan penonton bisa berbaur menjadi satu. Bentuk dari keunikan ini adalah saweran. Salah satu motivasi ramainya pertunjukkan Reyog Obyoganadalah adanya interaksi dan komunikasi antara penonton dengan pemain. Interaksi ini dapat berupa sapaan, mengajak menari bersama bahkan memberikan uang atau biasa disebut dengan saweran. Konco Reyog adalah sebutan bagi orang-orang yang antusias dan serta ikut menjadi bagian dari sebuah pertunjukkan Reyog Obyogan meskipun bukan bagian resmi dari tim Reyog yang sedang bermain.

Budaya Ponoragan sangat terasa dalam setiap pementasan dalam bentuk atau format obyogan ini adalah adanya rasa kebersamaan dan kesederhanaan serta solidaritas yang cukup tinggi diantara warga masyarakat Ponorogo itu sendiri. Hal ini tidak terlepas dari warga Ponorogo sendiri yang pada jaman dahulu masih kuat dalam memegang kepercayaan animisme dan dinamisme sehingga reyog sendiri menjadi bagian ritual dalam setiap pertunjukkannya. Secara fisik, bentuk reyog sendiri merupakan gabungan dari binatang merak dan harimau yang dalam filosofi budaya jawa sendiri mempunyai cerita-cerita mistis dibelakangnya.

Saweran sendiri merupakan sebuah tradisi dari masyarakat adat Sunda dimana orang tua kedua mempelai melemparkan uang ke penonton dengan harapan agar rejeki kedua mempelai selalu murah yang dilambangkan dengan uang, tidak pernah kekurangan pangan yang dilambangkan dengan beras, dan selalu dalam kehidupan yang manis yang dilambangkan dengan permen (Aryati, 2010, p. 36). Tetapi dalam pertunjukkan reyog sendiri, saweran diartikan sebagai memberikan uang kepada para penari jathil sebagai bentuk apresiasi menari bersama dengan penonton.

Pertunjukkan reyog Ponorogo dalam bentuk atau format obyogan adalah kesenian rakyat yang sedemikian rupa dimana memungkinkan konco reyog berinteraksi dengan pemain secara langsung. Hal inilah yang menjadi penyebab adanya saweran dalam pertunjukkan reyog obyogan. Tetapi hal demikian tidak selalu terjadi dalam pertunjukkan reyog obyogan. Peristiwa saweran ini dalam pengamatan peneliti hanya terjadi dibeberapa tempat seperti daerah timur Ponorogo seperti Ngebel dan Sawoo. 


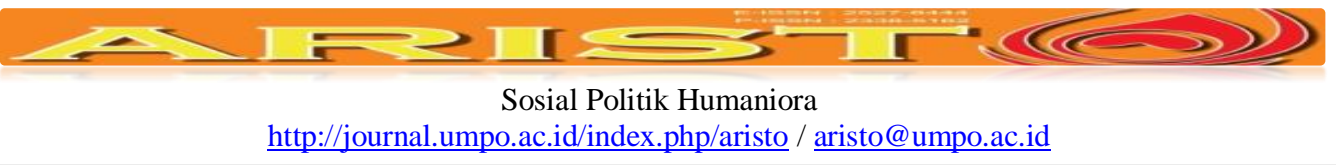

"Saweran ini mengacu pada kesenian tayub yang masih hidup dibeberapa daerah diPonorogo khususnya didaerah timur Ponorogo. Konsep saweran yang diterapkan dalam pertunjukkan reyog obyogan sangat berbeda dengan konsep saweran dalam tari tayub. Konsep saweran dalam tayub seakan tanpa kontrol oleh karena itu setiap orang dapat nyawer ke penari, tetapi dalam konsep saweran di reyog obyogan tidak seтиa orang dapat menari bersama jathil dan memberi saweran. Hanya orang yang berpengaruh dalam kelompok reyog tersebut atau orang yang berpengaruh didaerah itu yang dapat menari dengan jathil. Hal ini masih adanya rasa ewuh pekewuh (segan) dengan masyarakat setempat yang menjadi warok atau orang yang mempunyai pengaruh kuat dalam pementasan tersebut. (Wawancara dengan Drs.Rido Kurnianto, 20 Januari 2016).

Saweran dalam reyog obyogan sebenarnya tidak terlalu lazim atau dapat kita temui pada setiap pementasan reyog dalam bentuk obyogan. Saweran ini hanya ada pada daerahdaerah tertentu dengan loyalitas konco reyog yang cukup tinggi terhadap grup reyog tersebut atau adanya ikatan batin dengan grup reyog tersebut. Dengan demikian, saweran ini pun tidak bisa kita temui dalam setiap peetunjukkan reyog obyogan.peristiwa ini hanya dapat kita jumpai pada pertunjukkan reyog obyogan terutama pada daerah timur Ponorogo, diantaranya adalah daerah Ngebel, Sambit dan Sawoo.

Gambar 4.Saweran dalam pertunjukkan reyog Obyogan

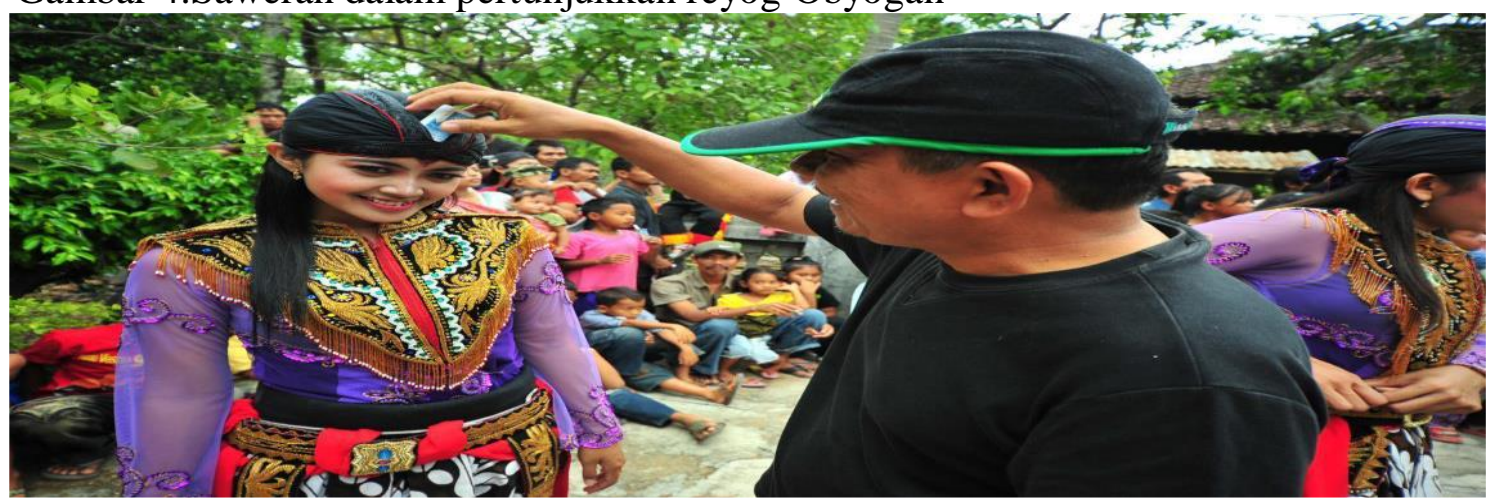

Sumber: diolah dari dokumentasi peneliti

Saweran sendiri merupakan sebuah jalan dalam berkomunikasi antara penari dan penonton dalam konteks interaksi. Hubungan antara penonton atau disebut sebagai konco reyog merupakan hubungan yang tidak bisa disamakan diantara kesenian yang lain. Interaksi antara konco reyog dengan penari atau pemain merupakan sebuah ikatan kekeluargaan dimana para penonton ini sangat menghormati dan menghargai para penari-penari yang tampil dalam pertunjukkan reyog obyogan ini. Komunikasi yang terjadi dalam interaksi pada pertunjukkan reyog ini merupakan yang terfokus pada hubungan jangka panjang dimana dalam menjaga hubungan persaudaraan ini antara pemain dan konco reyog sudah ada ikatan terlebih dahulu 


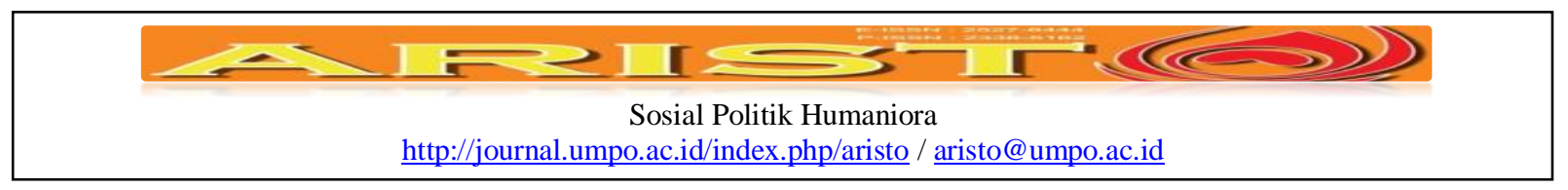

secara kekeluargaan. Ikatan ini merupakan bentuk yang tidak terlihat jika kita melihat langsung kepertunjukkan yang ada. Dalam pertunjukkan ini, seakan-akan kita melihat antara konco reyog dan penari tidak ada hubungan dengan masuk secara tiba-tiba di kalangan atau arena pertunjukkan.

Gambar 5. Saweran dalam bentuk yang lain kepada penari Bujangganong

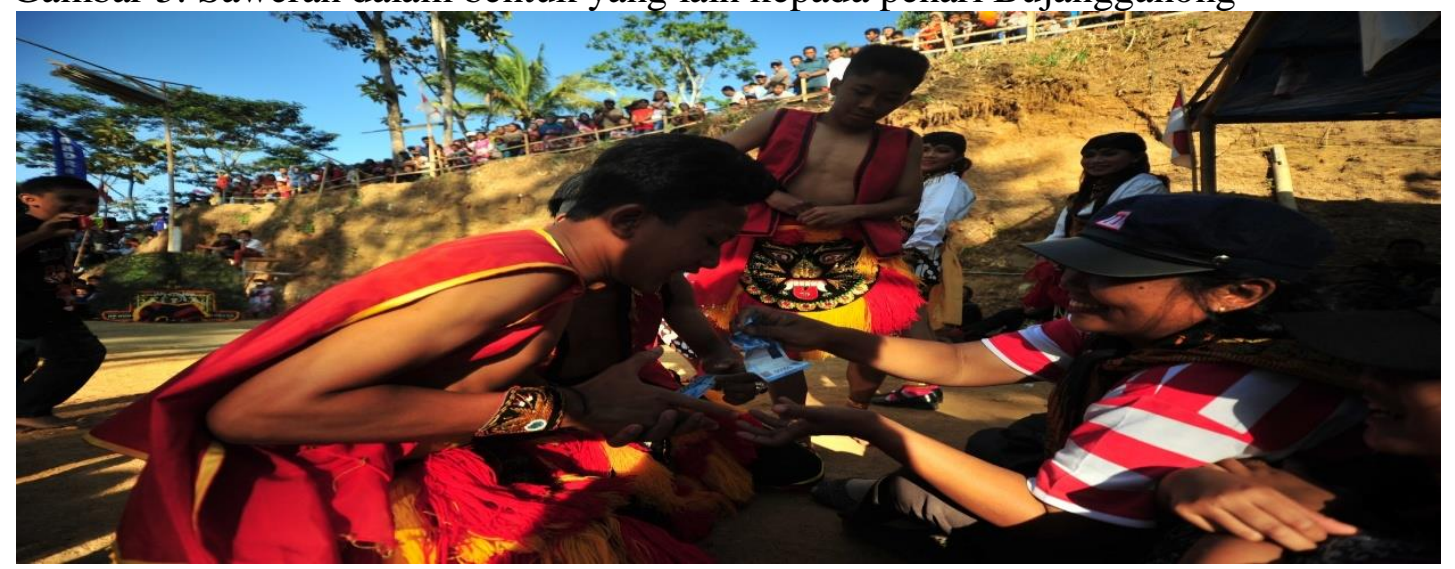

Sumber: diolah dari dokumentasi peneliti

\section{c. Edreg}

Salah satu ciri khas dalam pertunjukkan reyog obyogan adalah adanya satu gerakan tari yang disebut dengan edreg. edreg merupakan gerakan penari Jathil berjalan menyamping mendekati penari dadak merak atau bujangganong (Simatupang, 2013, p. 130) Gerakan tari dengan ciri khas menggoda dan terkadang agak seronok ini hanya terjadi dalam pementasan dalam reyog obyogan. Gerakan ini muncul setelah dadak merak mengamuk atau unjuk kebolehan didepan para konco reyog. Edreg ini hanya dapat kita temui dalam pementasan reyog obyogan saja. Dalam pertunjukan reyog obyogan, tidak hanya penari dadak merak saja yang terbuai oleh penari jathil, tetapi terkadang penari Bujangganong juga terbuai akan goyangan dari penari jathil ini.

Gerakan edreg yang hanya ada di reyog dengan format obyogan ini masih merupakan misteri. Beberapa pakar atau orang yang telah lama berkecimpung dalam kesenian reyog inpun masih belum bisa menjelaskan konsep dari edreg itu secara detil. Menurut mitos atau sejarah yang berkembang, gerakan edreg ini merupakan sindiran atau satire dari Ki Ageng Kutu dari Jetis kepada raja Bhre Kertabumi yang tunduk kepada istrinya.

"Edreg ini merupakan salah satu gerakan yang menggoda dari penari jathil kepada dadak merak yang sedang mengamuk, kemudian dadak merak itu seolah lemas kehilangan kesaktian setelah jathil menari didepannya, konsep dari edreg ini dalam hal 


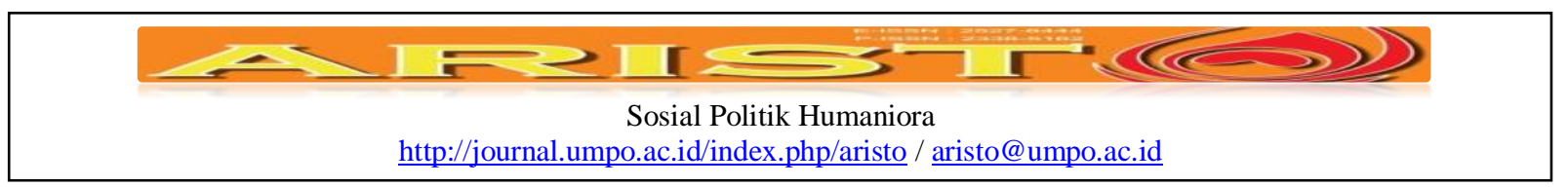

ini adalah hadiah dari jathil kepada dadak merak yang telah berhasil mengangkat dadak merak. jika dikaitkan dengan sindiran Ki Ageng Kutu terhadap Bhre Kertabumi yang tunduk pada istrinya dari cina, ini perlu kajian lebih mendalam”. (wawancara dengan Rido Kurnianto, 20 Januari 2016)

Edreg ini merupakan salah satu adegan dalam pertunjukkan reyog dan dipercaya salah satu asal muasal reyog Ponorogo versi Suryangalam. Mitos ini menceritakan tentang seorang pujangga dari kerajaan Majapahit pada masa pemerintahan Bhre Kertabumi pada akhir abad ke 15 yang bernama Ki Ageng Kutu Suryangalam. Ki Ageng Kutu Suryangalam kemudian menyingkir ke daerah Wengker dan tinggal didesa Kutu (sekarang masuk dalam wilayah kecamatan Jetis) dan mendirikan satu kesenian yaitu reyog. Hal ini disebabkan salah satu punggawa kerajaan itu merasa kerajaan Majapahit dalam krisis pemerintahan dimana raja bernama Bhre Kertabumi tunduk dan patuh pada istrinya yang berasal dari Cina (Simatupang, 2013, p. 117) Edreg sendiri mempunyai tabuhan khas yang disesuikan dengan lagu-lagu yang sedang hits pada saat sekarang terutama dalam aliran dangdut dengan irama koplo. Lagu-lagu tersebut masuk dan dijadikan tembang wajib jika menari dalam obyogan. Diantara lagu-lagu tersebut yang sedang ngetrend adalah "Buka sithik Joss", "Kanggo Riko" dan gending wajib yang harus ada adalah "walang kekek". Indikasi lagu-lagu yang trend dan dijadikan tembang dalam gending Ponoragan dapat didengar dalam acara Dangdut Ponoragan yang disiarkan oleh Radio Duta Nusantara setiap hari pukul 14.30-16.00.

\section{c.1 Edreg penari jathil ke Bujangganong}

Pertunjukkan reyog obyogan merupakan pertunjukkan yang unik dan menarik dari sisi interaksionisme yang terjadi antara penari satu dengan yang lain. Salah satu hal yang menarik ini adalah gerakan edreg dimana penari jathil menggoda penari bujangganong setelah melakukan atraksi atau melakukan baberapa aksi yang cukup menantang.

Gerakan edreg penari jathil terhadap penari bujangganong adalah sebuah peristiwa yang sering terjadi ada setiap pertunjukkan yang terjadi dalam pertunjukkan reyog obyogan. Penari bujangganong dituntut atraktif dan komunikatif terhadap penonton ataupun terhadap penari penari yang lain seperti bujangganong atau dadak merak sendiri.Biasanya gerakan ini dapat kita jumpai ketika penari bujangganong selesai melakukan atraksi dan duduk jongkok dengan bertumpu pada lutut sambil memandang salah satu jathil, maka dengan segera penari jathil akan menghampiri penari bujangganong tersebut denga gerakan bergoyang menyamping mendekati 


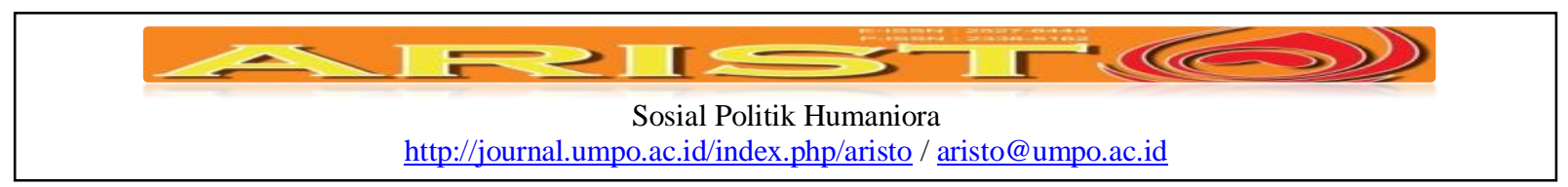

penari bujangganong.

"Edreg niki namung hiburan mawon, mboten wonten maksud punapa-punapa” (gerakan edreg ini sifatnya hanya hiburan saja, tidak ada maksud apa-apa). Demikian penjelasan dari mbah Misdi, salah satu tokoh dalam pertunjukkan reyog Ponorogo sejak tahun '60an. Hal ini juga dikuatkan pendapat dari tokoh reyog dari barat Ponorogo, Mbah Sinto yang mengatakan bahwa gerakan edreg penari jathil terhadap bujangganong merupakan hadiah setelah selesai melakukan atraksi-atraksi seperti salto, berputar diudara, berputar dengan kepala atau gerakan seperti penari hip-hop. "wontene edreg nggih namung damel gojegan mawon, mboten wonten pakemipun" (adanya gerakan atau edreg ini hanya untuk bahan tertawa atau senang-senang saja, tidak ada aturan pastinya), Wawancara dengan Mbah Sinto, seniman dari desa Krebet Jambon Ponorogo, 9 Januari 2016.

Gambar 6.Edreg penari jathil pada Bujangganong

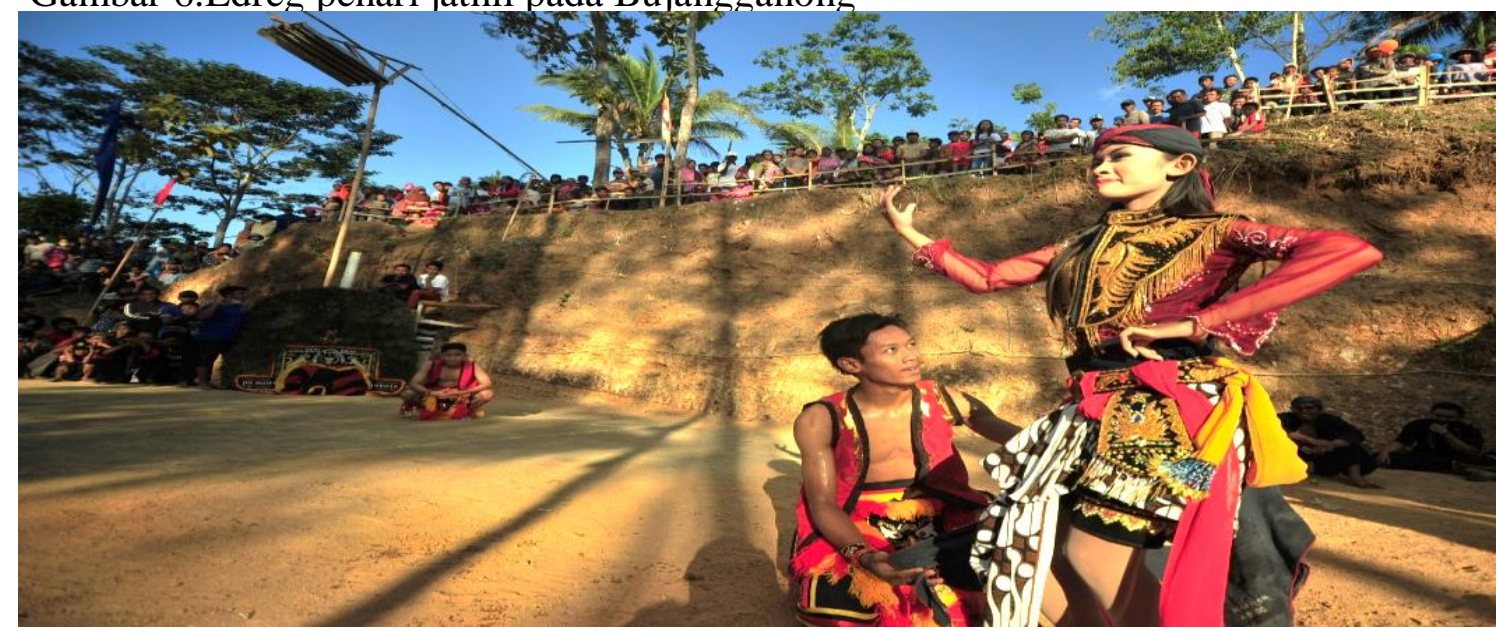

Sumber: diolah dari dokumentasi peneliti

\section{c.2 Edreg penari jathil ke dadak merak}

Edreg dalam pertunjukkan reyog obyogan merupakan sebuah atraksi tambahan atau tidak ada aturan tertulis. Oleh karena itu dalam pertunjukkan reyog festival tidak akan kita temui hal semacam ini. Edreg dalam pertunjukkan reyog obyog pun tidak diketahui secara pasti awal mulanya, atau siapa yang mempoulerkan, hal ini sifatnya hanya turun-temurun saja. Permainan edreg hanya ada dan dapat kita temui pada pemain dadak merak dan bujangganong saja. dengan demikian tidak akan kita temui pada pemain selain bujangganong dan dadak merak yaitu Klanasewandana atau penari warok. Hal ini sangat bertolak belakang dengan pementasan reyog festival diamana dadak merak digambarkan sedang bertarung dengan pasukan berkuda yaitu 


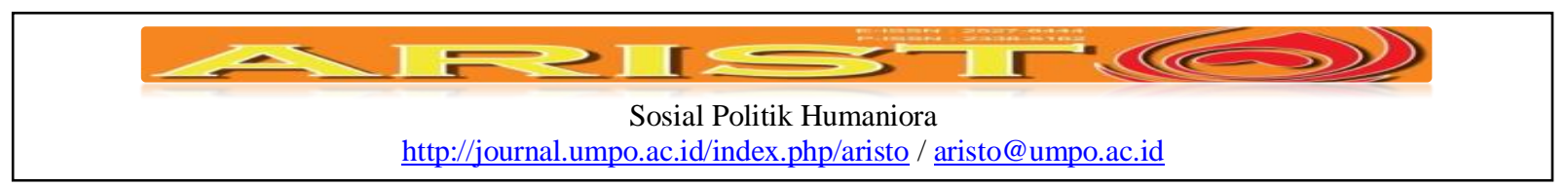

penari jathil, sedang didalam reyog obyogan dengan gerakan edreg ini keduanya seperti saling menggoda dan terkadang seronok atau menjurus ke arah erotis (Simatupang, 2013, p. 130).

Salah satunya adalah gerakan edreg dari penari jathil ke dadak merak. Hal ini akan kita temuai hampir disetiap pertunjukkan reyog obyogan yang ada diPonorogo. Gerakan ini dapat kita lhat pada setelah dadak merak atau kadang disebut panjak Barong melakukan atraksi dengan mengibaskan dadak meraknya segala arah, berguling, melompat dan seperti menerkam mangsa. Setelah itu, dadak merak akan duduk jongkok dengan memandang salah satu penari jathil, kemudian penari jathil akan melakukan gerakan menari menyamping sambil mendekat ke arah dadak merak tersebut.

Menurut pandangan beberapa orang pemerhati reyog, gerakan edreg antar pemain penari jathil dengan dadak merak memunyai maksud dan arti tersendiri. Hal ini sepeerti yang diungkapkan oleh Drs. Rido Kurnianto bahwa "edreg dalam permainan obyogan merupakan sindiran pada jaman suryangalam yang menyindir masa pemerintahan Bhre Kertabumi yang tunduk pada istrinya”.

Mbah Sinto menambahkan bahwa edreg dalam obyogan terutama antara pemain penari jathil dengan dadak merak merupakan gerakan dimana seorang yang sangat kuat dan gagah bisa tunduk dan manut pada kecantikan seorang yang cantik.

"dadak merak ingkang gagah, kuat, sekti mandraguna saksampunikpin wonten jathil ingkang ayu, nggih kados mboten wonten dayanipun, lemes lan namung saget lenggah. Nanging sak sampunipiun jathil niku lungo, nggih kiat malih.."(dadak merak yang semula kuat gagah dan sakti, setelah adanya penari jathil yang cantik seperti kehilangan kekuatan, lemas dan hanya bisa duduk. Tapi setelah penari jathil itu pergi maka dadak meak akan kuat lagi). Wawancara dengan Mbah Sinto, 9 Januari 2016

Gambar 7. Edreg penari jathil ke dadak merak

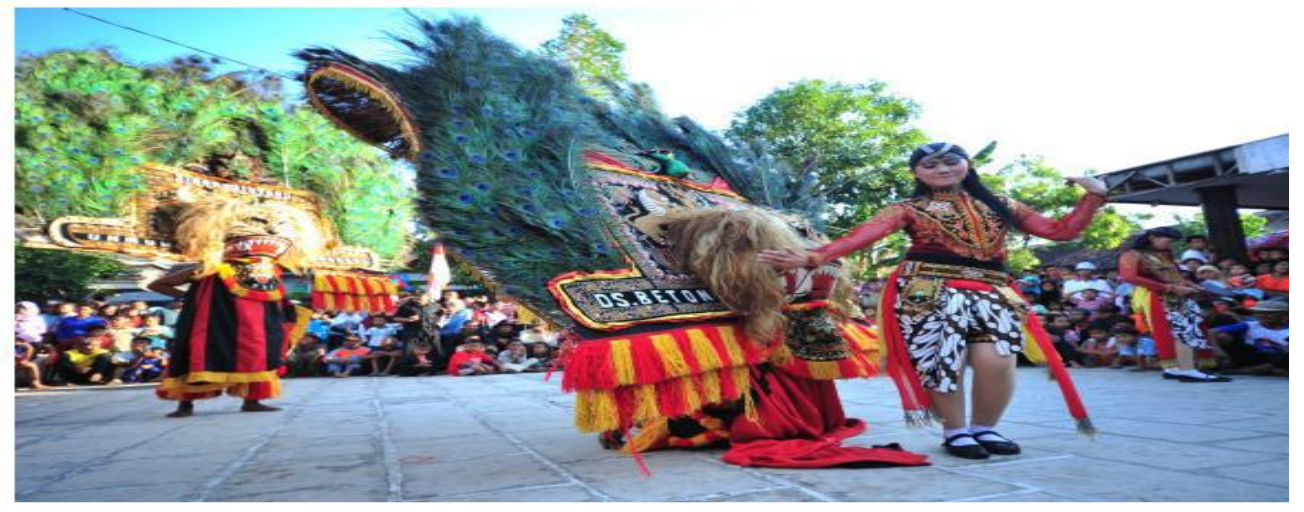

Sumber: diolah dari dokumentasi peneliti 


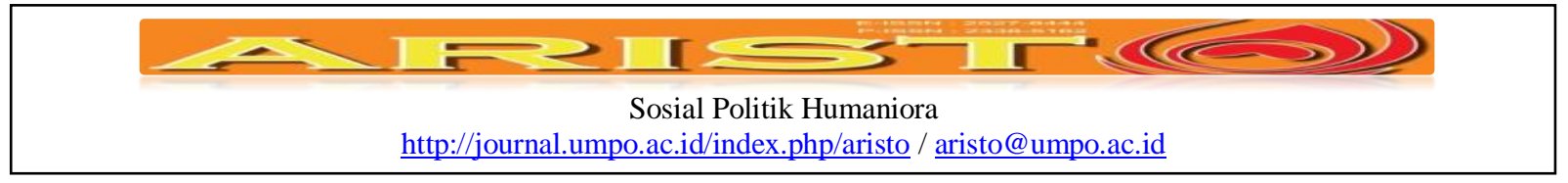

\section{c.3 Edreg penari jathil ke Konco reyog}

Salah satu keunikan lain yang hanya ada dan dapat kita temui pada pertunjukkan reyog obyog adalah adanya edreg dari penari jathil kepada konco reyog. Hal ini dapat terjadi karena adanya interaksi dan keterbukaan dalam pertunjukkan reyog obyogan itu sendiri. Hal ini tidak mungkin dapat kita temui dalam pertunjukkan reyog dengan format festival. Adanya interaksi yang bersifat terbuka antara pemain dan konco reyog membuat pertunjukkan reyog dimanapun berada akan menjadi tontonan yang selalu dinanti dan ramai oleh penonton.

Konco reyog merupakan fan base dari pertunjukkan reyog itu sendiri, diamana sebuah pertunjukkan reyog terutama reyog obyogan mempunyai sebuah fanatisme dengan bentuk yang unik. Keunikan ini adalah mereka tidak melihat sebuah sebuah grup reyog ini dari penampilan mereka yang terbaik, tetapi para konco reyog ini menilainya dari interaksi dengan para konco reyog yang hadir pada saat itu.

"Wujud partisipasi dalam reyog obyogan bisa beramacam-macam, tergantung dari daerah atau budaya setempat. Salah satu bentuk partisipasi adalah ikut bermain atau menjadi pemain untuk memeriahkan pertunjukkan reyog tersebut. Konco reyog bisa menjadi pemain Bujangganong, atau ikut menjadi pembarong tanpa harus menggunakan kostum lengkap. Sedangkan edreg disini hanya sebagai hiburan atau hadiah saja." (wawancara dengan drs.Rido Kurnianto, 20 Januari 2016)

Gambar 8. Edreg Penari jathil kepada konco reyog pada pertunjukkan reyog di desa Bungkal, Kecamatan Bungkal Ponorogo 22 agustus 2014

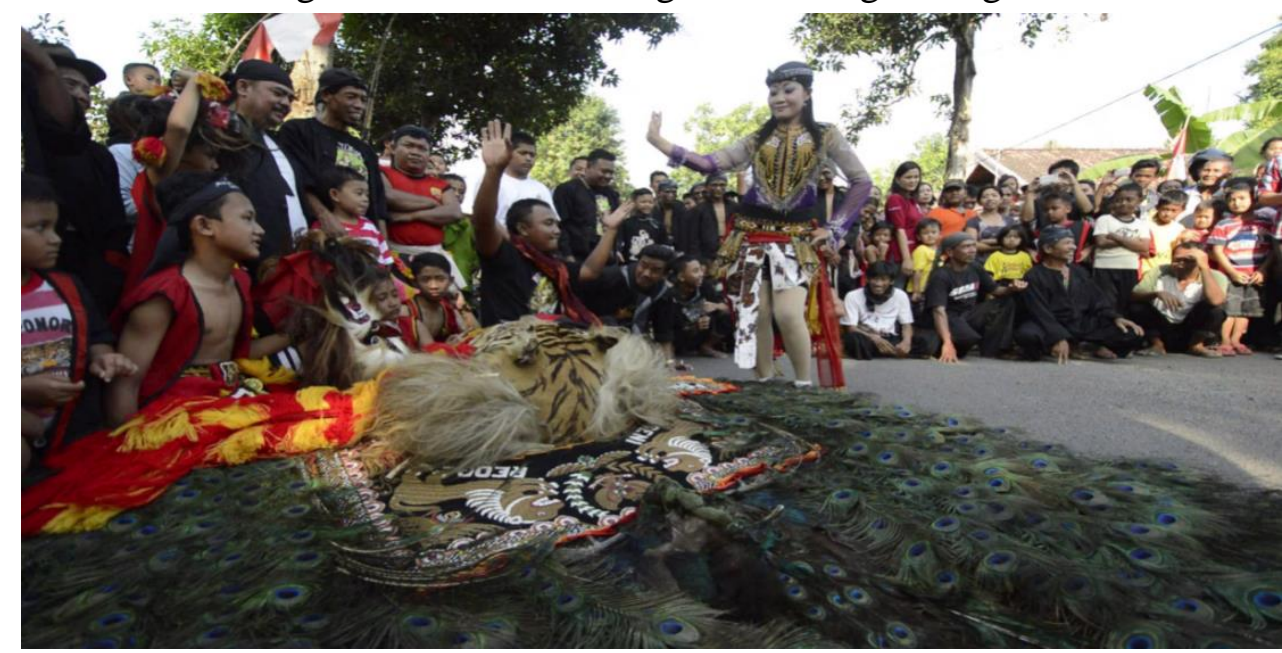

Sumber: diolah dari dokumentasi peneliti 


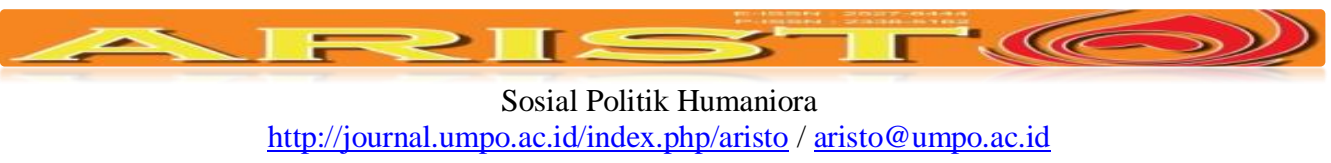

Kesimpulan

Pada peneltian tentang budaya populer dalam pertunjukkan reyog obyogan ini mendapatkan kesimpulan yang cukup penting dalam sebuah paradigma pertunjukkan tradisional. Pertunjukkan tradisional yang biasanya didominasi dengan pertunjukkan yang sederhana, berorientasi masa lalu dan cenderung monoton ternyata telah berubah dan berevolusi dalam perkembangannya. Beberapa evolusi yang terjadi mempunyai dampak langsung dalam pertunjukkan ini dimana pertunjukkan yang terjadi dapat dilihat langsung bentuk perubahannya dan terkadang mempengaruhi pesan dan makna dari pertunjukkan itu sendiri

Bentuk budaya populer yang terjadi pada pertunjukkan daerah taradisional terutama dalam reyog obyogan ini mempunyai satu benang merah yang dapat dijadikan sebuah kesimpulan utama. Satu kesimpulan utama tentang budaya populer dalam pertunjukkan reyog obyogan ini adalah adaptasi dan survivalitas. Bentuk-bentuk adapatasi yang terjadi dalam pertunjukkan reyog ini merupakan sebuah usaha dalam menjaga sebuah kelompok pertunjukkan ini tetap eksisdan terus berlanjut sampai waktu yang tidak ditentukan. Bentuk usaha ini pula yang menjadi inti tentang menjaga kelestarian budaya dalam setiap aspeknya baik dari sisi regenerasi, pengembangan dan kreativitas. Usaha-usaha inilah yang menjadikan reyog seperti yang kita lihat sekarang dengan paragidma yang bermacam-macam dan bentuk pertunjukan yang dinamis dari satu pertunjukkan ke pertunjukkan yang lain atau dari satu tempat ke tempat yang lain.

Bentuk budaya populer yang lain adalah pemakaian asesoris dalam sebuah lingkungan kerja formal seperti sepatu kerja kantor yang jika kita rasakan kurang begitu pas jika dihubungkan dengan konteks pertunjukkan reyog obyogan jalanan. Reyog dalam pertunjukkan jalanan bergerak secara cepat dan berpindah dari satu tempat ke tempat lain. Disamping itu, sepatu kerja ini kurang cocok dipakai dalam lingkungan yang berdebu dan panas seperti dilapangan. Tetapi para penari ini mempunyai anggapan yang lain tentang sepatu kerja ini. Sepatu kerja ini dianggap paling sesuai dalam representasi pasukan berkuda yang selalu memakai sepatu dalam aktifitasnya.

Perangkat pertunjukkan juga tidak luput dari sentuhan budaya populer yang ada dimasyarakat. Sentuhan-sentuhan ini terkadang mengaburkan makna dari sebuah makna pertunjukkan itu sendiri. Sebagai contoh adalah dengan berusaha menghilangkan ebleg atau jaran kepangdalam menari jathil. Hal ini merupakan sebuah usaha dalam mengikuti kemauan dimasyrakat dimana para konco reyog ini menginginkan jathil tampil bukan lagi sebagai pasukan 


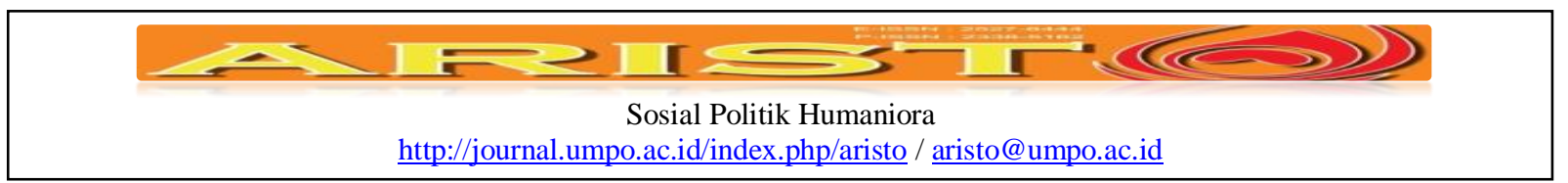

berkuda, tetapi lebih sebagai penari layaknya penari jaipong. Dengan demikian gerakan yang ditampilkan juga berbeda dengan tari pasukan berkuda.

Gending dan tembang mengalami perubahan yang dinamis dalam prakteknya. Gending atau lagu pengiring dalam reyog obyogan selalu bergerak mengikuti perkembangan trend lagu yang sedang hitsdimasyarakat. Lagu-lagu ini merupakan lagu-lagu dalam genre dangdut atau campursari yang mudah dipahami oleh masyarakat desa dengan alunan music yang dinamis dan rancak. Pada awalnya lagu-lagu yang ada merupakan ganding seperti 'walang kekek' atau 'kebogiro' tetapi sekarang seiring perkembangan jaman, gending-gending yang dimainkan lebih banyak dan variatif seperti 'kanggo riko', 'buka sitik joss' atau yang lain. Dengan demikian, gending yang dimainkan lebih banyak diserap dari lagu-lagu yang digemari masyarakat sekarang. Hal yang tidak mungkin dilaukan dalam pertunjukkan reyog festival.

Drama pertunjukkan merupakan sebuah rangkaian peristiwa yang terjadi dalam sebuah pertunjukkan reyog obyogan. drama ini merupakan sebuah konsep spontanitas atau kejadiankejadian yang tidak direncanakan sebelumnya, tetapi pada prakteknya terjadi dan menjadi sebuah tren yang disukai pada kalangan konco reyog. Kejadian-kejadian tersebut meliputi, atraksi dan gojegan, saweran dan edreg. atraksi atau gojegan ini merupakan usaha dari bujangganong dalam menghidupkan suasana yang atraktif dan menarik dalam sebuah pertunjukkan. Usaha-usaha ini biasanya dalam bentuk bujangganong melakukan atraksi yang mengundang tawa atau lainnya yang disebut dengan gojekan. Saweran juga menjadi sebuah bentuk drama pertunjukkan yang mulai marak dalam sebuah pertunjukkan reyog obyogan. Tetapi saweran ini juga tidak setiap waktu dan tempat dapat kita temui. Hal yang sangat populer dalam sebuah pertujukkan reyog adalah adanya edreg. Edreg ini merupakan sebuah bentuk pertunjukkan yang dapat kita temui dalam setiap pertunjukkan reyog obyogan. seakan menjadi sebuah kesepatapakatan bersama bahwa dalam sebuah pertunjukkan reyog obyogan terdapat edregan dalam setiap pertunjukkannya. 


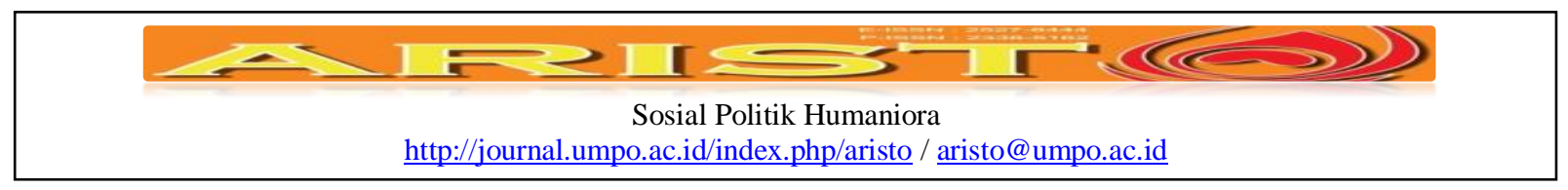

\section{Daftar Pustaka}

Aryati, L. (2010). Menjadi MC Acara Pernikahan. Jakarta: Gramedia Pustaka Utama.

Bruce David Forbes, J. H. (2005). Religion and Popular Culture in America. california: university california press.

Bungin, B. (2008). Penelitian Kualitatif. Jakarta: Kencana.

F. Leong, E. C. (1994). The Role of Ethnic Identity and Acculturation in the Vocational Behavior of Asian Americans: An Integrative Review (Vol. 44). Journal of Vocational Behavior.

Geertz, C. (1976). The Religion of Java. Chicago: the university of Chicago press. jawa pos radar madiun. (1999, September 16 ). Reyog Ponorogo Memilih hujan emas di negeri orang redup ditanah kelahiran. jawa pos radar madiun, hal. 3.

Jazuli. (1994). Telaah Teoretis Seni Tari. Semarang: IKIP Semarang Press.

Katie Milestone, A. M. (2012). Gender and Popular Culture. cambridge: polity press.

Kumorohadi, T. (2004). Reyog Obyogan Perubahan dan Keberlanjutan Cara Penyajian dalam Pertunjukan Reyog Ponorogo.

Kumorohadi, T. (2004). Reyog Obyogan Perubahan dan Keberlanjutan Cara Penyajian dalam Pertunjukan Reyog Ponorogo. Surakarta: PPS STSI.

Kurnianto, R. (2007). Laporan Hasil Penelitian.Pencitraan Perempuan Dalam Kasus Perubahan Pelaku Jathil Dari Laki-Laki Menjadi Perempuan Pada Seni Reyog Ponorogo. Ponorogo: LPPM Unmuh Ponorogo.

Kurnianto, R. (2007). Pencitraan Perempuan Dalam Kasus Perubahan Pelaku Jathil Dari LakiLaki Menjadi Perempuan Pada Seni Reyog Ponorogo. Ponorogo: LPPM Unmuh Ponorogo (Unpublished).

Larry A. Samovar, R. E. (2009). Communication Between Cultures. Boston: Wadsworth Cengage Learning.

Lawrence E. Harrison, S. P. (2000). Culture Matters: How Values Shape Human Progress. New York: basic book.

Marcel, D. (2012). Popular Culture: Introductory Perspectives. Maryland: rowman \& Littlefiled Publisher Inc.

Martono, H. (2012, Mei). Reyog dalam Profesi. Jurnal Tari "Joged", 3(1), 94. 


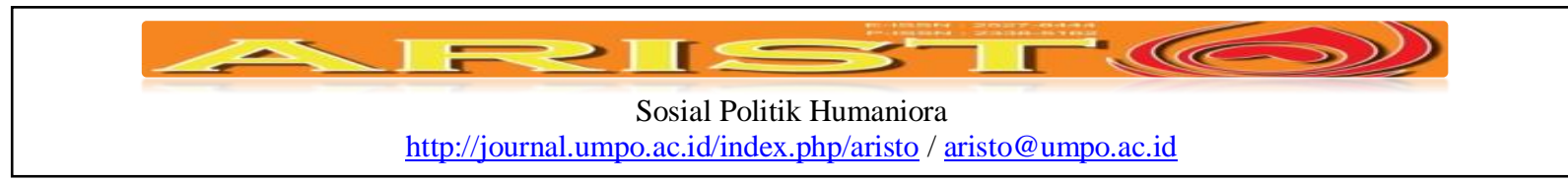

Moleong, L. J. (2000). Metodologi Penelitian Kualitatif. Bandung : Remaja Rosdakarya.patton. (t.thn.).

pemkab ponorogo. (2013, april 3). Kabupaten_Ponorogo. Diambil kembali dari id.wikipedia.org: (http://id.wikipedia.org/wiki/Kabupaten_Ponorogo)

Ponorogo, Pemkab. (1993). Pedoman Dasar Kesenian Reyog Ponorogo dalam Pentas Budaya Bangsa. ponorogo: pemkab ponorogo.

Ponorogo, Pemkab. (1993). Pedoman Dasar Kesenian Reyog Ponorogo dalam Pentas Budaya Bangsa. ponorogo: pemkab ponorogo.

Simatupang, L. (2013). Pergelaran.Sebuah Mozaik Penelitian Seni Budaya. Yogyakarta: JalaSutra.

Williams, R. (1983). Writing in Society. london: verso. 